\title{
SOLAR ENERGY SYSTEM PERFORMANCE EVALUATION - SEASONAL REPORT FOR SOLARON-DUFFIELD, DUFFIELD, VIRGINIA
}

\section{Prepared by}

IBM Corporation

Federal Systems Division

150 Sparkman Drive

Huntsville, Alabama 35805

Under Contract NAS8-32036 with

National Aeronautics and Space Administration

George C. Marshall Space Flight Center, Alabama 35812

For the U. S. Department of Energy

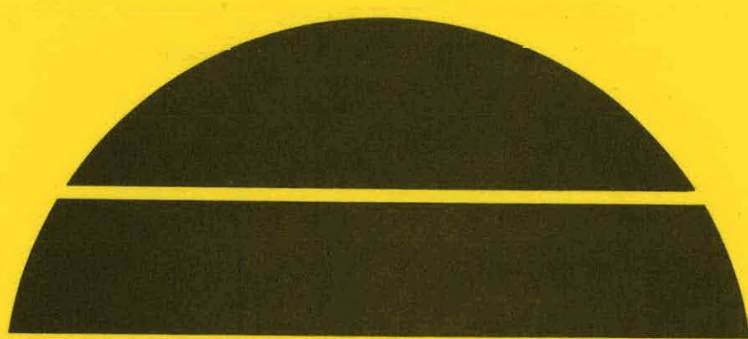

\section{U.S. Department of Energy}




\section{DISCLAIMER}

This report was prepared as an account of work sponsored by an agency of the United States Government. Neither the United States Government nor any agency Thereof, nor any of their employees, makes any warranty, express or implied, or assumes any legal liability or responsibility for the accuracy, completeness, or usefulness of any information, apparatus, product, or process disclosed, or represents that its use would not infringe privately owned rights. Reference herein to any specific commercial product, process, or service by trade name, trademark, manufacturer, or otherwise does not necessarily constitute or imply its endorsement, recommendation, or favoring by the United States Government or any agency thereof. The views and opinions of authors expressed herein do not necessarily state or reflect those of the United States Government or any agency thereof. 


\section{DISCLAIMER}

Portions of this document may be illegible in electronic image products. Images are produced from the best available original document. 
NOTICE

Th1s report was prepared to document work sponsored by the United States Government. Ne1ther the UnIted States nor 1ts agents the United States Department of Energy, the United States Nat1onal Aeronautics and Space Administration, nor any federal employees, nor any of their contractors, subcontractors or the1r employees, make any warranty, express or implied, or assume any lagal 11ability or responsibllity for the accuracy, completeness, or usefulness of any information, apparatus, product or process disclosed, or represent that its use would not Infringe privately owned rights. 
TECHNICAL REPORT STANOARD TITLE PAGE

\begin{tabular}{|c|c|}
\hline $\begin{array}{l}\text { 1. REFTAR :Ia. } \\
\text { DOE/NASA CR-161507 }\end{array}$ & 3. RECIPIENT'S CATALOG NO. \\
\hline \multirow{2}{*}{$\begin{array}{l}\text { 4. TITLE AND SUBTITLE } \\
\text { Solar Energy System Performance Evaluation - Seasonal } \\
\text { Report for Solaron-Duffield, Duffield, Virginia }\end{array}$} & $\begin{array}{l}\text { 5. REPORT DATE } \\
\text { July } 1980 \\
\end{array}$ \\
\hline & 6. PERFORMING ORGANIZATION CC.DE \\
\hline 7. AUTHOR(S) & 8. PEAFORMING ORGAMIZATION REPOA $\mathrm{F}$ \\
\hline \multirow{2}{*}{$\begin{array}{l}\text { 9. PERFoRming ORGAMIZATION MAME AND AODRESS } \\
\text { IBM Federal Systems Division } \\
\text { 150 Sparkman Drive } \\
\text { Huntsville, Alabama } 35805\end{array}$} & 10. WORK UNIT. NO. \\
\hline & $\begin{array}{l}\text { 11. CONTRACT OR GRANT NO. } \\
\text { NAS } 8-32036\end{array}$ \\
\hline \multirow[t]{2}{*}{$\begin{array}{l}\text { 12. SPONSORING AGENCY NAME ANO AOORESS } \\
\text { National A eronautics and Space Administration } \\
\text { Washington, DC } 20546\end{array}$} & $\begin{array}{l}\text { 13. PYPE OF REPOR: Q PERIOD COVERED } \\
\text { Contractor Report } \\
\text { October } 1979- \\
\text { Märch } 1980\end{array}$ \\
\hline & 14. SPONSORING AGENCY CODE \\
\hline
\end{tabular}

15. SUPPLEMENTARY NOTES

This work was done under the technical management of Mr. Cecil W. Messer, George C. Marshall Space Flight Center, Alabama.

\section{ABSTRACT}

This report developed for the George C. Marshall Space Flight Center as a part of the Solar Heating and Cooling Development Program funded by the Department of Energy is one of a series of reports describing the operational and thermal performance of a variety of solar systems installed in Operational Test Sites.

The Snlaron Duffield Solar Energy Syslem was designed to provide 51 percent of the space heating, and 49 percent of the domestic hot water (DHW) to a two story 1940 square foot area residence using air as the transporc medium. The system corisists of a 429 square foot collector array, a 265 cubic foot rock thermal storage bin, heat exchangers, an 80 gallon DHW preheat tank, pumps, blowers, controls, air ducting and associated plumbing. An air-to-liquid heat pump coupled with a 1,000 gallon water storage tank provides for auxiliary space heating and can also be used for space cooling. A 52 gallon electric DHW tank using the solar preheated water provides domestic hot water to the residence. The solar system, which became operational July. 1979, has the following modes of operation: A) First Stage: 1) Collector to storage and DHW, 2) Collector to Space Heating, 3) Storage to Load, B) Second Stage: 4) Heat Pump Auxiliary Direct, 5) Auxiliary Heat From Heat Pump Storage, C) Third Stage: 6) Electrical Resistance (Strip) Heat.

\begin{tabular}{|c|c|}
\hline 17. KEY WOROS & $\begin{array}{l}\text { 18. OISTA18UTIOM STATEMEMT UC-59C } \\
\text { Unclassified-Unlimited }\end{array}$ \\
\hline & $\begin{array}{l}\text { Woocanc. } \\
\text { WILLIAM A. BROOKSBANK, /JR. } \\
\text { Mgr., Solar Energy Applications Projects }\end{array}$ \\
\hline
\end{tabular}

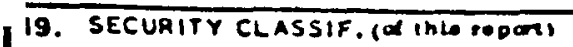
20. SECUATTY CLASSIF. (of inde pace) Unclassified Unclassified 80 NT IS 
THIS PAGE

\section{WAS INTENTIONALLY LEFT BLANK}


TABLE OF CONTENTS

SECTION

TITLE

PAGE

1.

2.

2.1

2.2

3.

3.1

3.2

3.2 .1

3.2 .2

3.2 .3

3.2 .4

4.

5.

6.

7.

8.

APPENDIX A

APPENDIX B

APPENDIX $C$

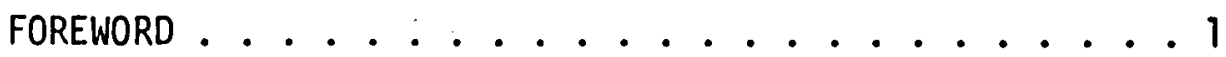

SYSTEM DESCRIPTION ............. 2

TYPICAL SYSTEM OPERATION. ........ 6

SYSTEM OPERATING SEQUENCE .......... . . 9

PERFORMANCE ASSESSMENT . . . . . . . . . . 11

SYSTEM PERFORMANC.F. ............. . . .

SUBSYSTEM PERFORMANCE ........... . . . . .

COLLECTOR ARRAY SUBSYSTEM. . . . . . . . 21

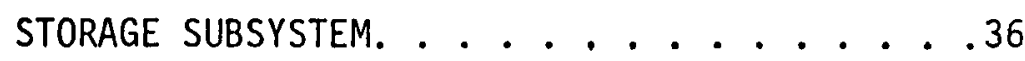

HOT WATER SUBSYSTEM. ..................

SPACE HEATING SUBSYSTEM. . ........42

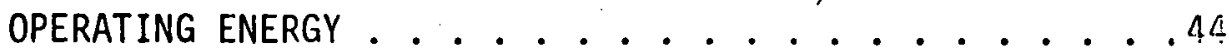

ENERGY SAVINGS .................... . .

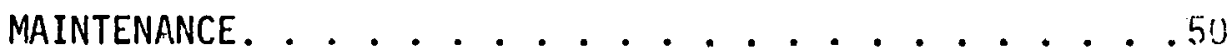

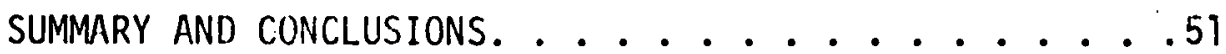

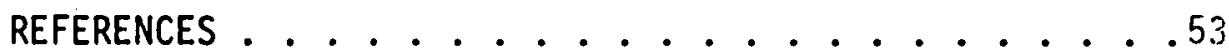

DEFINITIONS OF PERFORMANCE FACTORS AND SOLAR TERMS . . .A-1

SOLAR ENERGY SYSTEM PERFORMANCE EQUATIONS. . . . . . . . B-

LONG-TERM AVERAGE WEATHER CONDITIONS .......... . . r

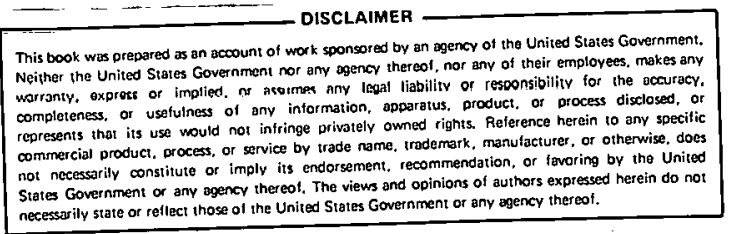

iii

DISTRIBUTION OF THS BOCUMERT IS UASLFITES 


\section{LIST OF FIGURES AND TABLES}

2-1

2.1-1

2.2-1

$3.1-1$

3.2.1-1

3.2.1-2

$3.2 .1-3$

TABLE

$3.1-1$

3.2.1-1

3.2.1-2

3.2.2-1

$3.2 .3-1$

$3.2 .4-1$

4-1

$5-1$
Solaron Duffield Solar Energy System Schematic . . . . 3 Typical System Operating Parameters. . ... . . . 7 Typical System Operating Sequence. . . . . . . 10 Solar Energy System Evaluation Block Diagram . . . . . 14 Collector Details. . . . . . . . . . . . . . 22 Solaron Duffield Collector Efficiency Curves . . . . . .30 Solaron Duffield Operating Point Histograms for Typical Winter and Transitional Months . . . 35

TITLE

PAGE

Sýstem Performance Summary . . . . . . . . . 16

Collector Array Performance. . . . . . . . . . 23

Energy Gain Comparison . . . . . . . . . . . . . 32

Storage Subsystem Performance. . . . . . . . . . 38

Hot Water Subsystem Performance. . . . . . . . . . .40

Heating Subsystem Performance. . . . . . . . . 43

Operating Energy . . . . . . . . . . . . . . . . .

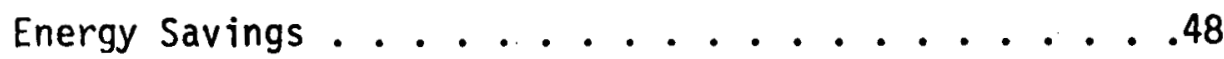




\section{FOREWORD}

The Solar Energy System Performance Evaluation - Seasonal Report has been developed for the George C. Marshall Space Flight Center as a part of the Solar Heating and Cooling Development Program funded by the Department of Energy. The analysis contained in this document describes the technical performance of an Operational Test site (OTS) functioning throughout a specified period of time which is typically one season. The objective of the analysis is to report the long term performance of the installed system and to make technical contributions to the definition of techniques and requirements for solar energy system design.

The contents of this document have been divided into. the following topics of discussion:

- System Description

- Performance Assessment

- Operating Energy

- Energy Savings

- Maintenance

- Summary and Conclusions

Data used for the seasonal analyses of the Operational Test Site described in this document have been collected, processed and maintained under the ors Development Program and have provided the major inputs used to perform the long term technical assessment.

The Seasonal Report document in conjunction with the Final Report for each Operational Test Site in the Development Program culminates the technical activities which began with the site selection and instrumentation system design in April 1976. The Final Report emphasizes the economic analysis of solar systems performance and features the payback performance based on life cycle costs for the same solar system in various geographic regions. Another document speciffically related to this system is Reference [1].*

*Numbers in brackets designate references found in Section 8. 


\section{SYSTEM DESCRIPTION}

The Solaron Duffield Solar Energy System was designed to provide both space heating and domestic hot water (DHW) preheating for a two story. single-family residence containing approximately 1940 square feet in Duffield, Virginia. Solar energy collection is accomplished with flatplate collectors using air as the transport fluid. The collector array has a gross area. of 429 square feet and faces south at an angle of 40 degrees from the horizontal. Solar energy is stored in a 265 cubic foot rock thermal storage bin located on the lower level of the house. Solar energy is transterred to the DHW subsystem by mcans of an in-duct. heat exchanger ( $H \times 1)$ whenever the system is storing collected solar energy. Water from the 80 gallon preheat tank is transferred to the 52 gallon DHW tank when there is a denldild for hot water. The auxiliary space heating subsystem consists of an air to liquid heat pump coupled with a 1000 gallon water storage tank. The heat pump can provide energy either directly to the house or to the 1000 gallon tank. The system is designed so that the heat pump can charge the 1000 gallon tank during off-peak hours when electrical rates are lower. The heat pump with the off-peak storage can aiso be used for cooling. Energy stored in the tank can then be used for space heating purposes as required. Auxiliary energy for both the space heating and and DHW subsystems is provided by electricity. The heat pump has a nominal capacity. of $30,000 \mathrm{Btu} / \mathrm{Hr}$. with supplemental heat strips rated at $12 \mathrm{~kW}$, and the auxiliary hot water heater is rated at $4.5 \mathrm{kw}$ : The system is shown schematically in Figure 2-1, and sensor designations in Figure 2-1 are in accordance with NBSIR-76-1137 [2]. The measurement symbol prefixes: $W, T$, EP, and I represent respectively: flow rate, temperature, electric power, and insolation. The system has the following modes of operation:

\section{A. First Stage}

1. Collector to Storage and DHW. In this mode the collector blower transfers solar energy from the collector array to the rock thermal storage bin through the DIW heat exchanger. Part of the solar energy is utilized in the DHW preheat loop and the remaining solar energy is delivered to storage. This mode is entered 


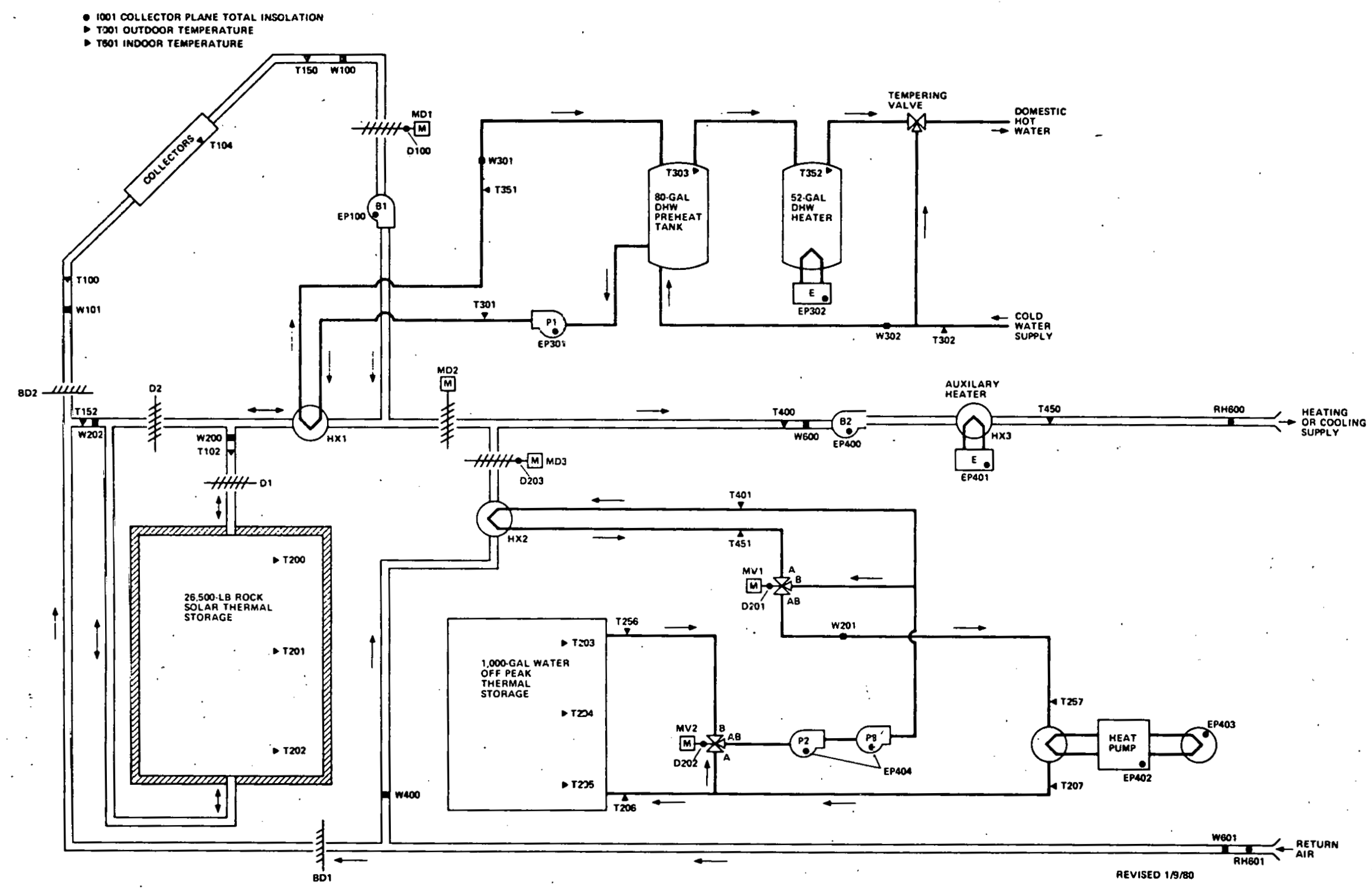

Figure 2-1 Solaron Duffield Solar Energy System Schematic 
whenever the differential temperature between the collectors and the return air duct is $40 \pm 7^{\circ} \mathrm{F}$ and heating demands are such that direct space heating from the collector array is not required. This mode terminates whenever the differential temperature falls to $25 \pm 5^{\circ} \mathrm{F}$, or less, or direct space heating from the collector array is required.

2. Collector to Space Heating Load. In this mode dampers MDI and MD2 are open and solar energy goes directly to the residential area utilizing both the collector and circulating blowers. The DHW heat exchanger is bypassed in this mode and all collected energy is delivered to the space heating load. The same differential temperature conditions described above also control operation in this mode.

3. Storage to Load. When incident solar energy on the collector array is insufficient, space heating is provided from the storage bin by way of the circulating blower. Dampers MDI and MD3 are closed in this mode and MD2 is open. A minimum storage temperature of $90^{\circ} \mathrm{F}$ is required for operation in this mode.

\section{B. Second Stage}

4. Heat Pump Auxiliary Direct. When insufficient solar energy is present on the collector array and the storage temperature is: also insufficient to maintain a level of comfort, dampers MDI and MD2 close and MD3 opens to provide heated air from the heat pump by way of the auxiliary heating/cooling heat exchanger. At outdoor temperatures of approximately $40^{\circ} \mathrm{F}$ or above, the heat pump will carry the entire space heating load. For temperatures between $2^{\circ} \mathrm{F}$ and approximately $40^{\circ} \mathrm{F}$, the heat pump is supplemented by the electrical strip heaters.

It is also possible to heat in this mode while, at the same time, collected solar energy is being delivered to storage. This 
condition exists whenever the room thermostat is calling for. second stage heating and sufficient insolation is available to allow the collector array to operate.

5. Auxiliary Heat from Heat Pump Storage. This mode allows space heating from the off-peak water storage tank. During off-peak hours, when the heat pump is not needed to heat the residence, it stores hot water for use during this mode. Dampers MDI and MD2 are closed and MD3 is open in this mode.

\section{Third Stage}

6. Electrical resistance (strip) heat is used whenever the heat pump is unable to maintain the desired comfort level in the house. Above $2^{\circ} \mathrm{F}$ the strips supplement the heat pump, as described in Mode 4 above, and below $2^{\circ} \mathrm{F}$ the strips carry the entire load. 


\subsection{Typical System Operation}

Curves depicting typical system operation on a cold, mostly bright day (February 3,1980 ) are presented in Figure 2.1-1. Figure 2.1-1 (a) shows the insolation on the collector array and the period when the array was operating (shaded area). Also shown in Figure 2.1-1 (a) are the collector array temperature profiles. These are the inlet temperature (T1OO), the outlet temperature (TI5O) and the absorber plate temperature (T104).

On this particular day the collector array began operating at 0938 hours. At that time the insolation level was $178 \mathrm{Btu} / \mathrm{Ft}^{2}-\mathrm{Hr}$ and the absorber plate temperature $(\mathrm{T104})$ was $99^{\circ} \mathrm{F}$. At the same time the collector array inlet temperature $(\mathrm{T} 100)$ was $52^{\circ} \mathrm{F}$.

The collector array operated normaliy throughout the day. It will be noted that 1104 tracked the insolation level quite closely during the operational period. The array outlet temperature (T150) also tracked both the insolation level and absorber plate temperature but its fluctuations were not as pronounced as those of the absorber plate temperature. The collector array inlet temperature (T1.00) showed a gradual rise almost constantly during the operational period. This is expected because the system was operating in the collector to storage and hot water mode most of the day. As a result T100 tended to track the temperature at the bottom of the storage bin fairly closely. The system ran until 1529 hours and then shut down for the day.

Figure 2.1-1 (b) presents a profile of the storage bin temperatures for the selected day. The system operated all day in either the collector to space heating mode or collector to storage and DHW preheating modes, depending on space heating demand. During the charging pertod the temperature profile in the storage bin behaved as would be expected, based on the air flow pattern through the storage bin and collector array outlet temperature (TI50). Once 
(a)

INSOLATION

(BTU/FT ${ }^{2}-\mathrm{HR}$ )

COLLECTOR

TEMPERATURES

( $\left.{ }^{\circ} \mathrm{F}\right)$

(b)

STORAGE

TEMPERATURE

( $\left.{ }^{\circ} \mathrm{F}\right)$

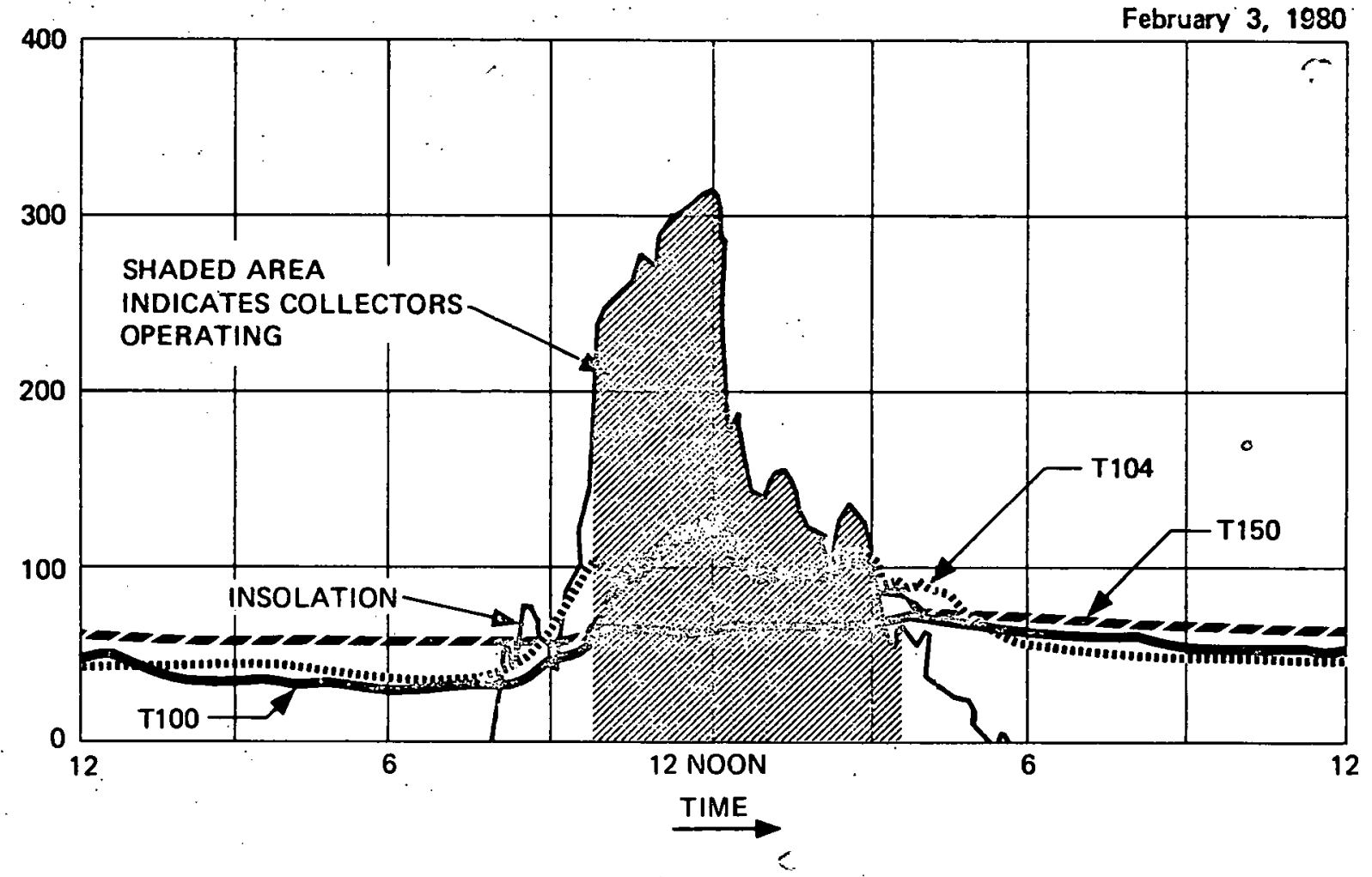

February 3, 1980

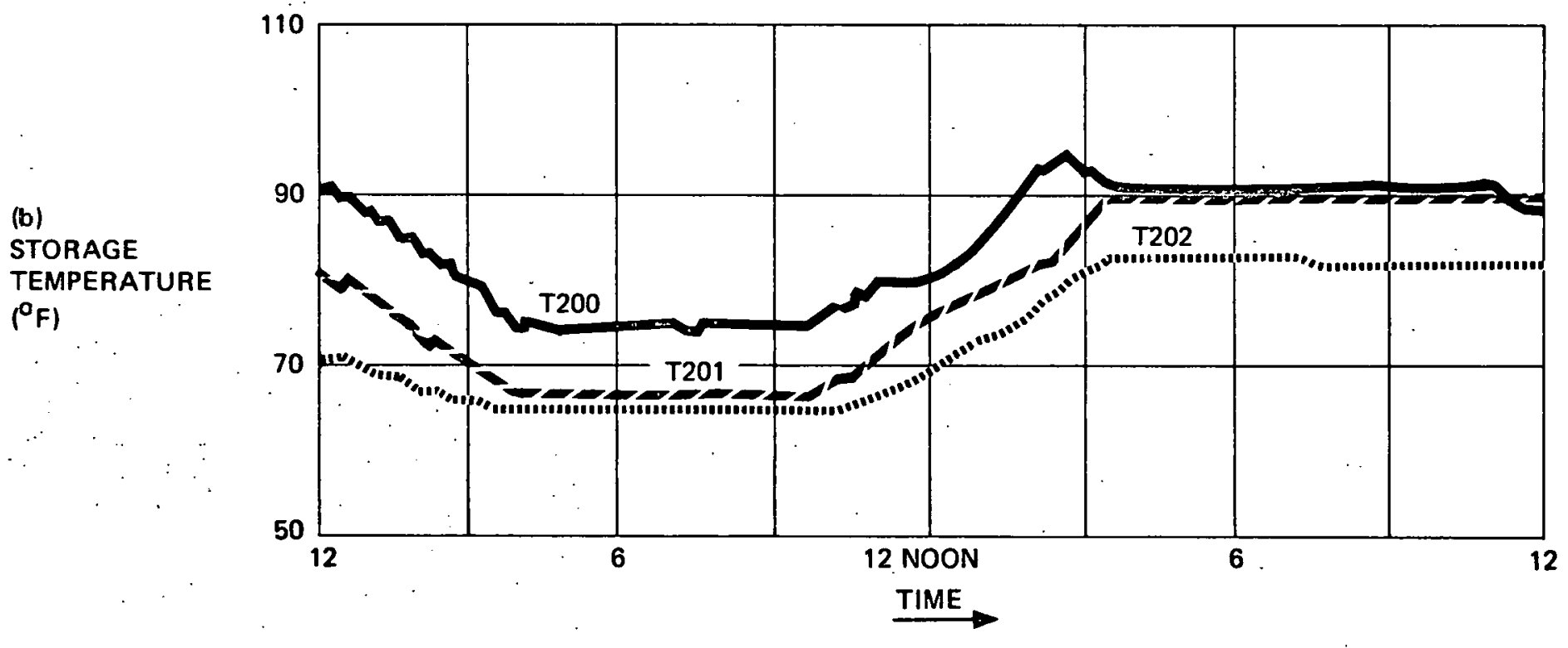

Figure 2.1-1. Typical System Operating Parameters 
collector array operation, and hence storage charging, ceased, the system remained relatively stable for the rest of the day, as the system did not enter the storage to space heating mode during the evening hours. 


\subsection{System Operating Sequence}

Figure 2.2-1 presents bar charts showing typical system operating sequences for February 3, 1980. This data correlates with the curves presented in Figure 2.1-1 and provides some additional insight into those curves. This particular day was chosen because almost all possible modes of system operation were exercised at some time during the day.

At the beginning of the day the system was operating intermittently in the rock storage to space heating mode and in the off-peak to storage mode. Operation continued in these modes until 0349, at which time the heat in rock storage was depleted and the system switched to the heat pump to space heating mode. Operation continued in this mode until 0749 hours, except for three short periods when the heat pump went into its defrost cycle and the heat strips came on. There was one brief period when the space heating demand was satisfied and the system switched briefly back to the off-peak to storage mode. The system operated in the off-peak to space heating mode until 0942 hours. At this time the collectors were operating and the system operated intermittently between the collector to space heating mode and the collector to storage and DHW preheating mode. At 1537 hours the system changed over to the heat pump to space heating mode and after 2210 hours operated intermittently between the heat pump to space heating mode and the heat pump to offpeak storage mode.

Domestic hot water usage for this day was considerably above the 61 gallons per day average for February. As shown in Figure 2.2-1, approximately 101 gallons of water was used during the day. Therefore, a higher than normal amount of auxiliary energy was required to support the DHW subsystem. 
SOLARAN DUFFIELD ... FEBRUARY 3, 1980

DHW USAGE (GAL)

AUXILIARY DHW HEAT

HEAT PUMP TO OFF

PEAK STORAGE

FEAT STRIPS TO SPACE HEATING \& DEFROST

OFF PEAK STORAGE TO SPACE HEATING

hEAT PUMP TO SPACE HEATING

STORAGE TO SPACE HEATING

COLLECTORS TO SPACE HEATING

COLLECTORS TO STORAGE AND DHW PREHEATING

COLLECTORS OPERATING

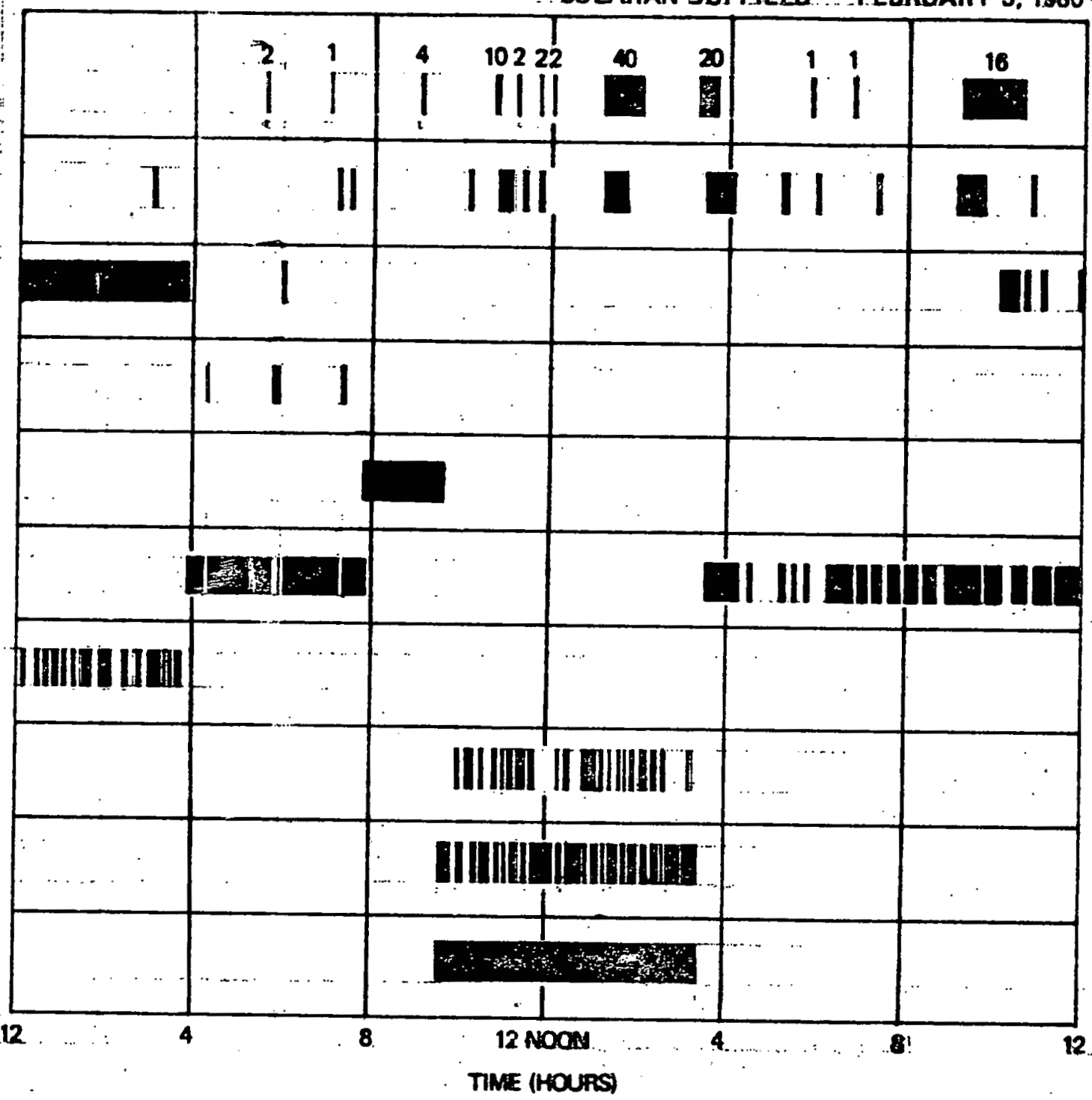

Figure 2.2-1 Typical System Operating Sequence 


\section{PERFORMANCE ASSESSMENT}

The performance of the Solaron Duffield Solar Energy System has been evaluated for the October 9, 1979 through March 1980 time period from two perspectives. The first was the overall system view in which the performance values of system solar fraction and net energy savings were evaluated against the prevailing and long-term average climatic conditions and system loads. The second view presents a more in-depth look at the performance of the individual subsystems. Details relating to the performance of the system are presented first in Section 3.1 followed by the subsystem assessment in Section 3.2.

For the purposes of this Solar Energy System Performance Evaluation, monthly performance data were regenerated to reflect refinements and improvements in the system performance equations that were incorporated as the analysis period progressed. These modifications resulted in changes in the numerical values of some of the performance factors. However, the basic trends have not been affected.

Before beginning the discussion of actual solar energy system performance some highlights and pertinent information relating to site history are presented in the following paragraphs.

The Solaron Duffield Solar Energy System was initially activated in August 1979. At that time all known system problems were addressed and corrected where possible. After the system was started up, a period of data monitoring was initiated to verify that the solar system and monitoring instrumentation were functioning properly.

During the initial check-out phase there were several problems identified relating to both the solar energy system and the monitoring instrumentation. 
Some of the more significant problems were: the heat pump operated in the cooling mode, but the compressor did not operate, flow imbalances throughout the system; and a significant amount of collector array leakage.

These problems, with the exception of the collector array leakage, were all corrected before the system entered the reporting phase in October 1979. The collector array leakage problem was accepted because it would have been very difficult (and costly) to correct it.

Once the system entered the reporting period there were very few instrumentation problems noted. However, control problems, especlally with the off-peak heating system, were noted throughout the reporting period. These problems, where applicable, have been addressed in the appropriate subsections. 


\subsection{System Performance}

This Seasonal Report provides a system performance evaluation summary of the operation of the Solaron Duffield Solar Energy system located in Duffield, Virginia. This analysis was conducted by evaluation of measured system performance against the expected performance with long-term average climatic conditions. The performance of the system is evaluated by calculating a, set of primary performance factors which are based on those proposed in the intergovernmental agency report, "Thermal Data Requirements and Performance Evaluation Procedures for the National Solar Heating and Cooling Demonstration Program" [2]. The performance of the major subsystems is also evaluated in subsequent sections of this report.

The measurement data were collected for the period October 1979 thorough March 1980. System performance data were provided through an IBM deve1oped Central Data Processing System (CDPS) [3] consisting of a remote Site Data Acquisition System (SDAS), telephone data transmission lines and couplers, an IBM System 7 computer for data management, and an IBM System 370/145 computer for data processing. The CDPS supports the collection and analysis of solar data acquired from instrumented systems located throughout the country. These data are processed daily and summarized into minthly performance formats which form a common basis for comparative system evaluation. These monthly summaries are the basis of the evaluation and data given in this report.

The solar energy system performance summarized in this section can be viewed as the dependent response of the system to certain primary inputs. This relationship is illustrated in Figure $3: 1-1$. The primary inputs are the incident solar energy, the outdoor ambient temperature and the system load. The dependent responses of the system are the system solar fraction and the total energy savings. Both the input and output definitions are as follows: 


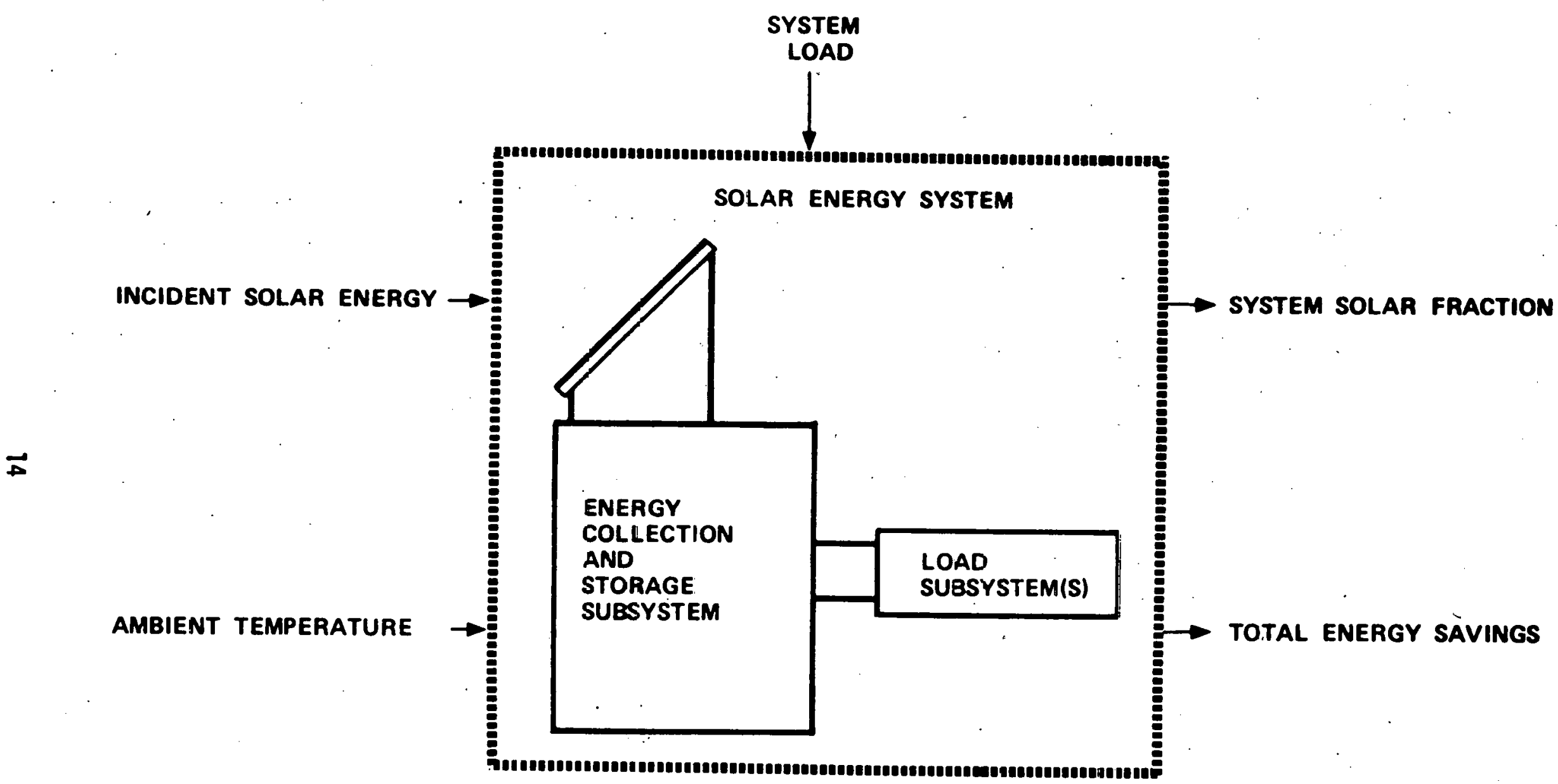

Figure 3.1.1 Solar Energy System Evaluation Block Diagram 
Inputs

- Incident solar energy - The total solar energy incident on the collector array and available for collection.

- Ambient temperature - The temperature of the external environment which affects both the energy that can be collected and the energy demand.

- System load - The loads that the system is designed to meet, which are affected by the life style of the user (space heating/cooling, domestic. hot water, etc., as applicable).

\section{Outputs}

- System solar fraction - The ratio of solar energy applied to the system loads to total energy (solar plus auxiliary energy) required by the loads.

- Total energy savings - The quantity of auxiliary energy (electrical or fossil) displaced by solar energy.

The monthily values of the inputs and outputs for the total operational period are shown in Table 3.1-1, the System Performance Summary. Comparative long-term average values of daily incident solar energy and outdoor ambient temperature are given for reference purposes. The long-term data are taken from Reference 1 of Appendix $C$. However, the 1ong-term data had to be based on actual data for Knoxville, Tennessee and Roanoke, Virginia, as there were no long-term data available for the Duffield, Virginia area. Appropriate weighting was applied to the Knoxville and Roanoke data to derive an estimate of the long-term conditions at Duffield.

Generally the solar energy system is designed to supply an amount of energy that results in a desired value of system solar fraction while operating under climatic conditions that are defined by the long-term average value of daily incldent solar energy and outdoor ambient temperature. If the actual 
TABLE 3.3-1

SYSTEM PERFORMANCE SUMMARY

\begin{tabular}{|c|c|c|c|c|c|c|c|c|c|}
\hline \multirow{2}{*}{ Month } & \multicolumn{2}{|c|}{$\begin{array}{l}\text { Daily Incident Solar } \\
\text { Energy Per Unit Area } \\
\left(40^{\circ} \text { Tilt) (Btu/Ft }{ }^{2}-\text { Day }\right.\end{array}$} & \multicolumn{2}{|c|}{$\begin{array}{l}\text { Ambient } \\
\text { Temperature } \\
\left({ }^{\circ} \mathrm{F}\right)\end{array}$} & \multirow{2}{*}{$\begin{array}{l}\text { System } \\
\text { Load - } \\
\text { Measured } \\
\text { (Million Btu) }\end{array}$} & \multicolumn{2}{|c|}{$\begin{array}{l}\text { Solar Fraction } \\
\text { (Percent) }\end{array}$} & \multirow{2}{*}{$\begin{array}{l}\quad \text { Total } \\
\text { Energy } \\
\text { Savings } \\
\text { (Million }\end{array}$} & \multirow{2}{*}{ Btu) } \\
\hline & Measured & $\begin{array}{c}\text { Long-Term } \\
\text { Average }\end{array}$ & Measured & $\begin{array}{l}\text { Cong-Term } \\
\text { Average }\end{array}$ & & Measured & Expected & & \\
\hline Oct 79 & 537 & 1,461 & 52 & 60 & 5.02 & 36 & 12 & 1.53 & \\
\hline Nov 79 & 895 & 1,184 & 46 & 48 & 9.72 & 63 & 43 & $\quad 4.24$ & . \\
\hline Dec 79 & 1,037 & 952 & 36 & 40. & 11.55 & 37 & 27 & 2.95 & \\
\hline $\operatorname{Jan} 80$ & 457 & 1,012 & 39 & 39 & 10.30 & 11 & 4 & 0.83 & \\
\hline Feb 80 & 956 & 1,210 & 31 & 41 & 12.06 & 47 & 24 & 3.69 & \\
\hline $\operatorname{Mar} 80$ & 873 & 1,421 & 42 & 48 & 8. 97 & 42 & 26 & 2.91 & \\
\hline Total & -- & -- & -- & -- & 57.62 & -- & -- & 16.15 & \\
\hline Average & 793 & 1,207 & 41 & 46 & 9.60 & 39 & 24 & 2.69 & \\
\hline
\end{tabular}


climatic conditions are close to the long-term average values, there is little adverse impact on the system's ability to meet design goals. This is an important factor in evaluating system performance and is the reason the long-term average values are given. The data reported in the following paragraphs are taken from Table 3.1-1.

At the Solaron Duffield site for the six month report period, the long-term average daily incident solar energy in the plane of the collector array was 1,207 Btu/Ft ${ }^{2}$. The average daily measured value was $793 \mathrm{Btu} / \mathrm{Ft}^{2}$, which is about 34 percent below the long-term value. On a monthly basis, October of 1979 was the worst month with an average dajly measured value of incident solar energy 63 percent below the long-term average daily value. December 1979 was the best month with an average daily measured value nine percent above the long-term average daily value.

The outdoor ambient temperature influences the operation of the solar energy system in two important ways. First the operating point of the collectors and consequently the collector efficiency or energy gain is determined by the difference in the outdoor ambient temperature and the collector inlet temperature. This will be discussed in greater detail in Section 3.2.1. Secondly the load is influenced by the outdoor ambient temperature. The long-term average daily ambient temperature for the six month period from October 1979 through March 1980 was $46^{\circ} \mathrm{F}$ at the Solaron Duffield site. This was 12 percent above the measured value of $41^{\circ} \mathrm{F}$.

Also presented in Table 3.1-1 are the measured and expected values of system solar fraction where system solar fraction is the ratio of solar energy applied to system loads to the total energy (solar plus auxiliary) applied to the loads. The expected values have been derived from a 
modified $f$-Chart analysis which uses measured weather and subsystem loads as inputs ( $f$-Chart is the designation of a procedure that was developed by the Solar Energy Laboratory, University of Wisconsin, Madison, for modeling and designing solar energy, systems [7]). The model used in the analysis is based on manufacturers' data and other known system parameters. The basis for the model is a set of empirical correlations developed for liquid and air solar energy systems that are presented in graphical and equation form and referred to as the $f$ Charts, where ' $f$ ' is a designator for the system solar.fraction. The output of the f-Chart procedure is the expected system solar fraction. The measured value of system solar fraction was computed from measurements, obtained through the instrumentation system, of the energy transfers that took place within the solar energy system. These represent the actual performance of the system installed at the site.

The measured value of system solar fraction can generally be compared with the expected value so long as the assumptions which are implicit in the $f$-Chart procedure reasonably apply to the system being analyzed. As shown in Table 3.1-1, the measured system solar fraction of 39 percent did not compare closely with the expected value of 24 percent generated by the modified $f$-Chart program. The modified $f$-chart simulation used for Seasonal Report Analysis with system losses approxinated is not a good prediction of the performance of the Solaron Duffield installation. The reasons for this are under investigation.

The total energy savings is the most important performance parameter for the solar energy system because the fundamental purpose of the system is to replace expensive conventional energy sources with less expensive solar energy. In practical consideration, the system must save enough energy to cover both the cost of its own operation and to repay the 
initial investment for the system. In terms of the technical analysis presented in this report the net total energy savings should be a significant positive figure. The total computed energy savings for the Solaron Duffield Solar Energy System was 16.15 million Btu, or $4,731 \mathrm{kWh}$, which was not a large amount of energy. However, this savings is based only on measured inputs of solar energy to the load subsystems. At the Solaron Duffield site there were a significant amount of uncontrolled (and hence unmeasured) inputs of solar energy into the house. These uncontrolled inputs of solar energy came primarily from storage and transport losses and tended to reduce the overall heating load, which in turn tended to increase real savings. This situation is addressed in more detail in the appropriate sections that follow. 


\subsection{Subsystem Performance}

The Solaron Duffield Solar Energy Installation may be divided into four subsystems:

1. Collector array

2. Storage

3. Hot water

4. Space heating

Each subsystem has been evaluated by the techniques defined in Section 3 and is numerically analyzed each month for the monthly performance assessment. This section presents the results of integrating the monthly data available on the four subsystems for the period October 1979 through March 1980. 


\subsubsection{Collector Array Subsystem}

The Solaron Duffield collector array consists of 22 Solaron 2000 series flat-plate air collectors arranged in two parallel rows of 11 collectors each. These collectors are a one-pass air heating type with a double glazing. Typical flowrate through the collector array is approximately 3.01 CFM per square foot of gross array area. Details of the air flow path are shown in Figure 3.2.1-1 (a) and a photograph of the collector array installation is presented in Figure 3.2.1-1 (b). The collector subsystem analysis and data are given in the following paragraphs.

Collector array performance is described by the collector array efficiency. This is the ratio of collected solar energy to incident solar energy, a value always less than unity because of collector losses. The incident solar energy may be viewed from two perspectives. The first assumes that all available solar energy incident on the collectors must be used in determining collector array efficiency. The cfficiency is then expressed by the equation:

$$
n_{c}=Q_{s} / Q_{i}
$$

where

$$
\begin{aligned}
& n_{c}=\text { Collector array efficiency } \\
& Q_{s}=\text { Collected solar energy } \\
& n_{i}=\text { Incident solar energy }
\end{aligned}
$$

The efficiency determined in this manner includes the operation of the control system. For example, solar energy can be available at the collector, but the collector absorber plate temperature may be below the minimum control temperature set point for collector loop operation, thus the cnergy is not collected. The monthly efficiency by this method is listed in the column entitled "Collector Array Efficiency" in Table 3.2.1-1. 


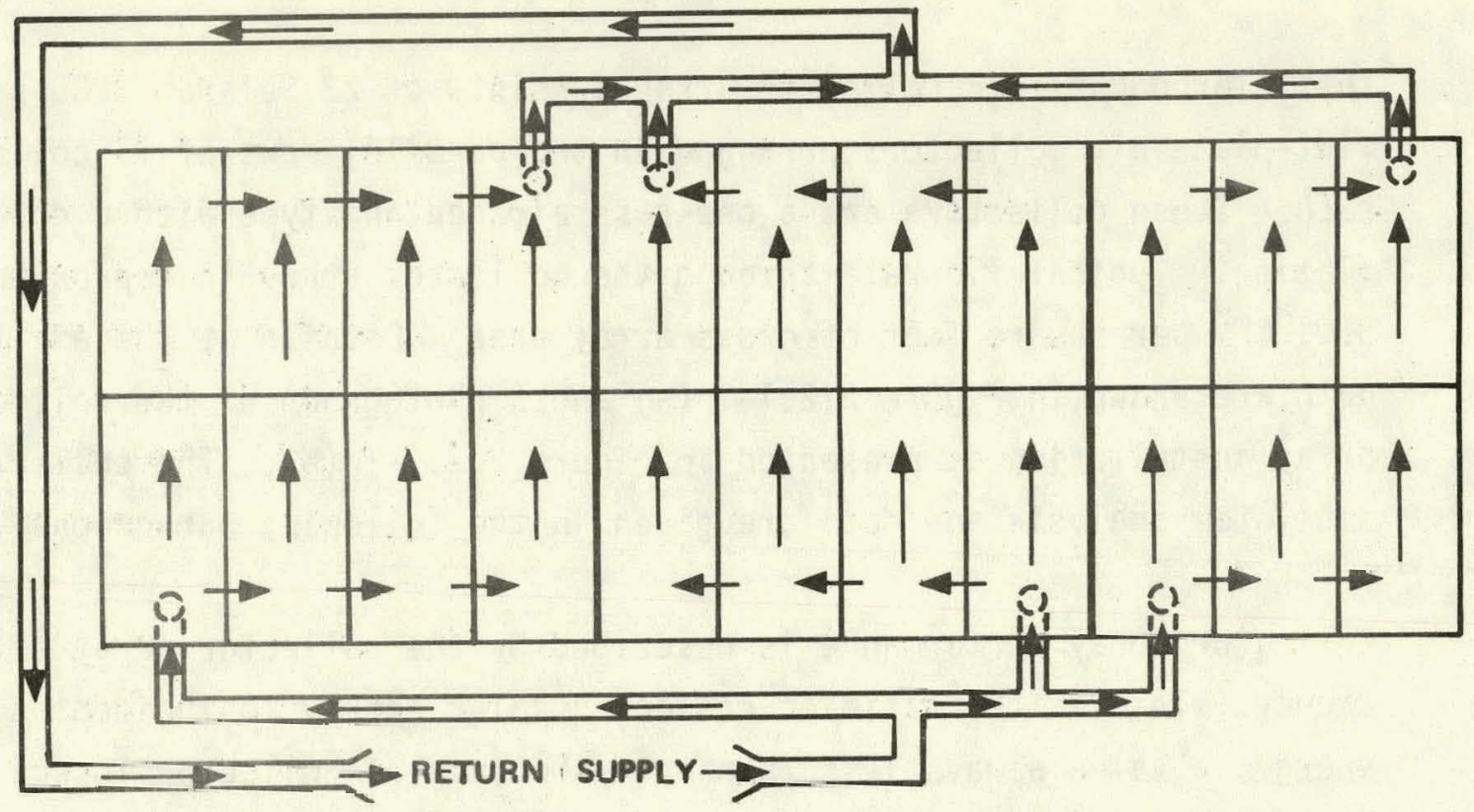

(a) Collector Air Flow Path

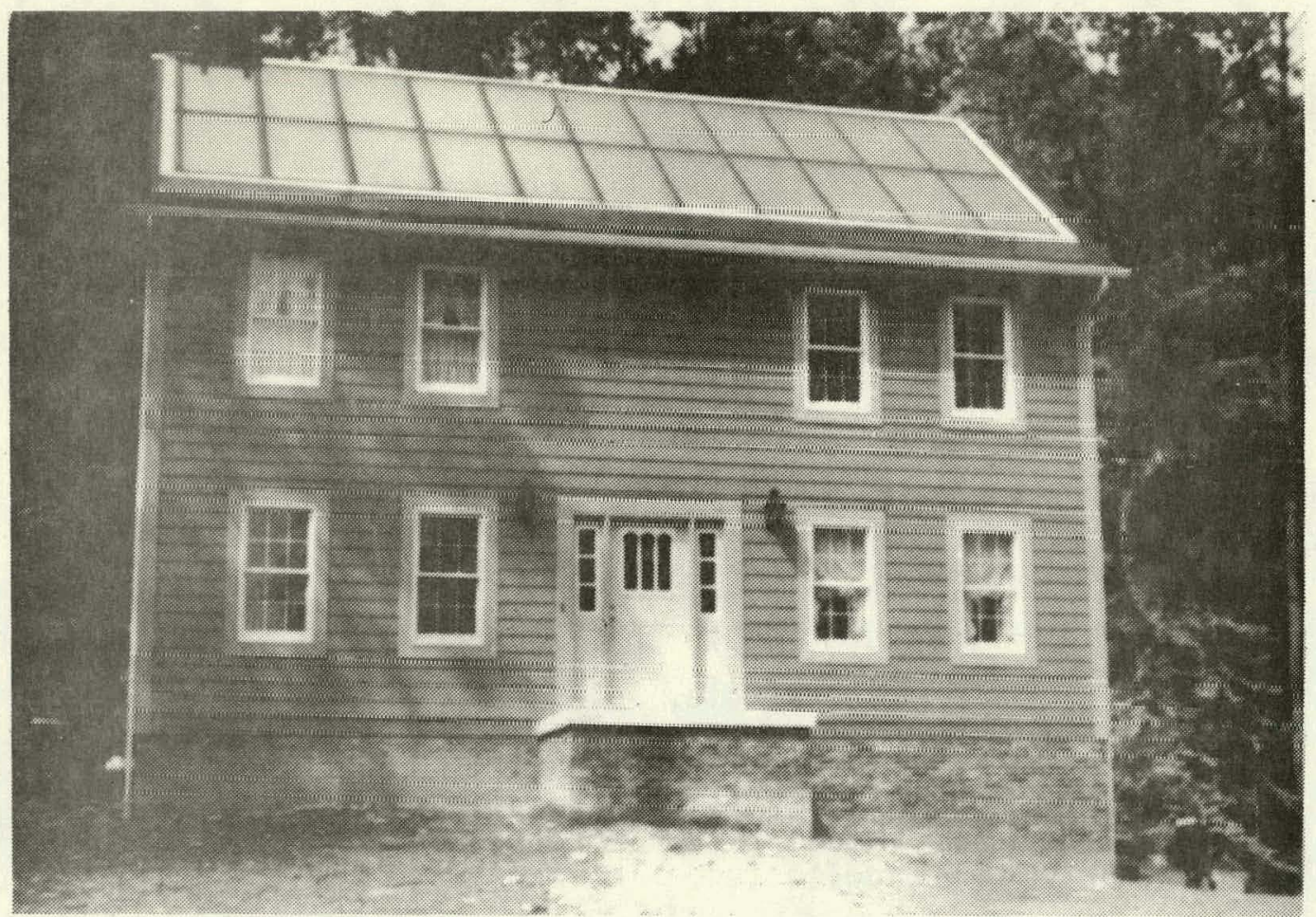

(b) Collector Array Installation

\begin{tabular}{l} 
COLLECTOR ARRAY \\
\hline Tilt Angle $-40^{\circ}$ \\
Azimuth - Due South
\end{tabular}

SITE LOCATION

Latitude $-36.48^{\circ} \mathrm{N}$

Longitude $-82.40^{\circ} \mathrm{W}$

FIgure 3.2.1-1 Collector Detalls 
TABLE $3.2 .1-1$

COLLECTOR ARRAY PERFORMANCE

\begin{tabular}{|c|c|c|c|c|c|}
\hline Month & $\begin{array}{l}\text { Incident } \\
\text { Solar Energy } \\
\text { (Million Btu) }\end{array}$ & $\begin{array}{l}\text { Collected } \\
\text { Solar Energy } \\
\text { (Million Btu) }\end{array}$ & $\begin{array}{l}\text { Collector } \\
\text { Array } \\
\text { Efficiency }\end{array}$ & $\begin{array}{c}\text { Operational } \\
\text { Incident Energy } \\
\text { (Million Btu) }\end{array}$ & $\begin{array}{c}\text { Operational } \\
\text { Collector Array } \\
\text { Efficiency }\end{array}$ \\
\hline $\operatorname{Oct} 79$ & 7.14 & 2.64 & 0.37 & 4.01 & 0.66 \\
\hline Nov 79 & 11.52 & 4.37 & 0.38 & 8.31 & 0.53 \\
\hline Dec 79 & 13.80 & 5.38 & 0.39 & 10.31 & 0.52 \\
\hline Jan 80 & 6.07 & 1.51 & 0.25 & 2.88 & 0.52 \\
\hline Feb 80 & 11.89 & 5.17 & 0.43 & 8.85 & 0.58 \\
\hline Mar 80 & 11.61 & 4.38 & 0.38 & 8.34 & 0.53 \\
\hline Total & $\ldots 62.03$ & . 23.45 & -- & 42.70 & -- \\
\hline Average & 10.34 & 3.91 & 0.38 & 7.12 & 0.55 \\
\hline
\end{tabular}


The second viewpoint assumes that only the solar energy incident on the collector when the collector loop is operational be used in determining the collector array efficiency. The value of the operational incident solar energy used is multiplied by the ratio of the gross collector area to the gross collector array area to compensate for the difference between the two areas caused by installation spacing. The efficiency is then expressed by the equation:

$$
n_{c o}=Q_{s} /\left(Q_{0 i} \times A_{p} / A_{a}\right)
$$

$$
\text { where } \begin{aligned}
{ }_{c 0}= & \text { Operational collector array efficiency } \\
Q_{s}= & \text { Collected solar energy } \\
Q_{0 i}= & \text { Operational incident solar energy } \\
A_{p}= & \begin{array}{l}
\text { Gross collector area (the product of } \\
\text { the number of collectors and the } \\
\text { envelope area of one collector) }
\end{array} \\
A_{a} & =\begin{array}{l}
\text { Gross collector array area (total area } \\
\text { including all mounting and connecting } \\
\text { hardware and spacing of units) }
\end{array}
\end{aligned}
$$

The monthly efficiency computed by this method is listed in the column entitled "Operational Collector Array Efficiency" in Table 3.2.1-1. 
In the ASHRAE Standard 93-77 [4] a collector efficiency is defined in the same terminology as the operational collector array efficiency. However, the ASHRAE efficiency is determined from instantaneous evaluation under tightly controlled, steady state test conditions, while the operational collector array efficiency is determined from actual dynamic conditions of daily solar energy system operation in the field.

The ASHRAE Standard 93-77 definitions and methods often are adopted by collector manufacturers and independent testing laboratories in evaluating the collectors. The collector evaluation performed for this report using the field data indicates that there was some difference between the laboratory single panel collector data and the collector data determined from long-term field measurements. This may or may not always be the case, and there are two primary reasons for differences when they exist:

- Test conditions are not the same as conditions in the field, nor do they represent the wide dynamic range of field operation (i.e. inlet and outlet temperature, flow rates and flow distribution of the heat transfer fluid, insolation levels, aspect angle, wind conditions, etc.). It is to be noted that the performance of air collectors is particularly sensitive to the air flow rate with higher efficiencies being achieved by increases in the air flow rate through the collectors.

- Collector tests are not generally conducted with units that have undergone the effects of aging (i.e. changes in the characteristics of the glazing material, collection of dust, soot, pollen or other foreign material on the glazing, deterioration of the absorber plate surface treatment, etc.).

Consequently field data collected over an extended period will generally provide an improved source of collector performance characteristics for use in long-term system performance definition. 
The long-term data base for Solaron Duffield includes only the months of November 1979, December 1979 and February 1980. Although the system was operating during the other three months of the report period the data was not included in the long-term base. In October 1979 data was only available for 12 days during the month. In both January and March of 1980 the data had too much scatter to provide any useful input to the long-term data base. Therefore, the long-term data base had to be constructed from the three months when good data was available.

The operational collector array efficiency data given in Table 3.2.1-1 are monthly averages based on instantaneous efficiency computations over the total performance period using all available data. For detailed collector analysis it was desirable to use a limited subset of the available data that characterized collector operation under "steady state" conditions. This subset was defined by applying the following restrictions:

(1) The measurement period was restricted to collector operation when the sun angle was within 30 degrees of the collector normal.

(2) Only measurements assoclated with positive energy gain from the collectors were used, i.e., outlet temperatures must have exceeded inlet temperatures.

(3) The sets of measured parameters were restricted to those where the rate of change of all parameters of interest during two regular data system intervals* was limited to a maximum of 5 percent.

\footnotetext{
*The data system interval was $5-1 / 3$ minutes in duration. Values of all measured parameters were continuously sampled at this rate throughout the performance period.
} 
Instantaneous efficiencies $\left(n_{j}\right)$ computed from the "steady state" operation measurements of incident solar energy and collected solar energy by Equation (2)* were correlated with an operating point determined by the equation:

$$
x_{j}=\frac{T_{i}-T_{a}}{T}
$$

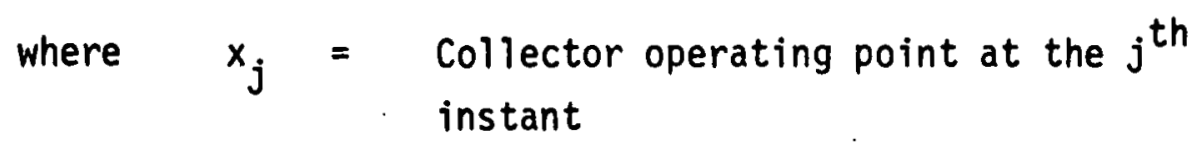

$T_{1}=$ Collector inlet fluid temperature

$T_{a}=$ Outdoor ambient temperature

I = Rate of incident solar radiation

The data points $\left(n_{j}, x_{j}\right)$ were then plotted on a graph of efficiency versus operating point and a first order curve described by the slopeintercept formula was fitted to the data through linear regression techniques. The form of this fitted efficiency curve is:

$$
n_{j}=b-m x_{j}
$$

where

$$
\begin{aligned}
n_{j} & =\begin{array}{l}
\text { Collector efficiency corresponding to the } \\
j^{\text {th }} \text { instant }
\end{array} \\
b & =\text { Intercept on the efficiency axis } \\
(-)_{m} & =\text { Slope } \\
x_{j} & =\begin{array}{l}
\text { Collector operating point at } j \text { th } \\
\text { instant }
\end{array}
\end{aligned}
$$

The relationship between the empirically determined efficiency curve and the analytically developed curve will be established in subsequent paragraphs.

*The ratio $A_{p} / A_{a}$ is assumed to be unity for this analys is. 
The analytically developed collector efficiency curve is based on the Hottell-Whillier-Bliss equation

$$
n=F_{R}(\tau \alpha)-F_{R} U_{L}\left(\frac{T_{i}-T_{a}}{T}\right)
$$

where $n=$ Collector efficiency

$F_{R}=$ Collector heat removal factor

$\tau=$ Transmissivity of collector glazing

$\alpha=$ Absorptance of collector plate

$U_{L}=$ Overall collector energy loss coefficient

$T_{i}=$ collector inlet fluid temperature

$T_{a}=$ Outdoor ambient temperature

$I=$ Rate of incident solar radiation

The correspondence between equations (4) and (5) can be readily seen. Therefore by determining the slope-intercept efficiency equation from measurement data, the collector performance parameters corresponding to the laboratory single panel data can be derived according to the following set of relationships:

$$
\begin{aligned}
& b=F_{R}(\tau \alpha) \\
& \text { and }=F_{R} U_{L}
\end{aligned}
$$

where the terms are as previously defined

The discussion of the collector array efficiency curves in subsequent paragraphs is based upon the relationships expressed by Equation (6). 
In deriving the collector array efficiency curves by the linear regression technique, measurement data over the entire performance period yields higher confidence in the results than similar analysis over shorter periods. Over the longer periods the collector array is forced to operate over a wider dynamic range. This eliminates the tendency shown by some types of solar energy systems to cluster efficiency values over a narrow range of operating points. The clustering effect tends to make the linear regression technique approach constructing a line through a single data point. The use of data from the entire performance period results in a collector array efficiency curve that is more accurate in long-term solar system performance prediction. The long-term curve and the curve derived from the laboratory single panel data are shown in Figure 3.2.1-2.

The long-term first order curve presented in Figure 3.2.1-2 indicates that the collector array as a whole seemed to perform better than the laboratory test unit. However, this is probably due to the fact that the performance equations for the collector array take into account the leakage of outside ambient air into the array. Also. the long-term first order curve has a slightly less negative slope than the curve derived from single panel laboratory test data. This is attributable to lower losses (other than leakage) resulting from array effects. In addition it should be noted that the operational collector efficiency values presented in Table 3.2.1-1 are high as compared to the long-term efficiency curve. This is probably due to the fact that the collector array normally operates one to two hours outside of the time period covered by the detailed collector analysis (sun angle within 30 degrees of the collector normal). During these early morning and late afternoon hours, but especially during the late afternoon, the leakage of outside ambient air into the collector array tends to raise the collector array efficiency a significant amount above the mid-day efficiency. Since the ambient air leakage is accounted for in all the efficiency calculations, the values reported in Table 3.2.1-1 can be higher than would be expected based on the long-term analysis alone. The laboratory predicted instantaneous efficiency is not in close agreement with the curve derived from actual field operation. This indicates that the laboratory derived curve might not be useful for design purposes in an array configuration of this type. However, this statement must be tempered by the fact that actual performance might approach predicted performance more closely if there were no leakage problems with the collector array or ductwork. 


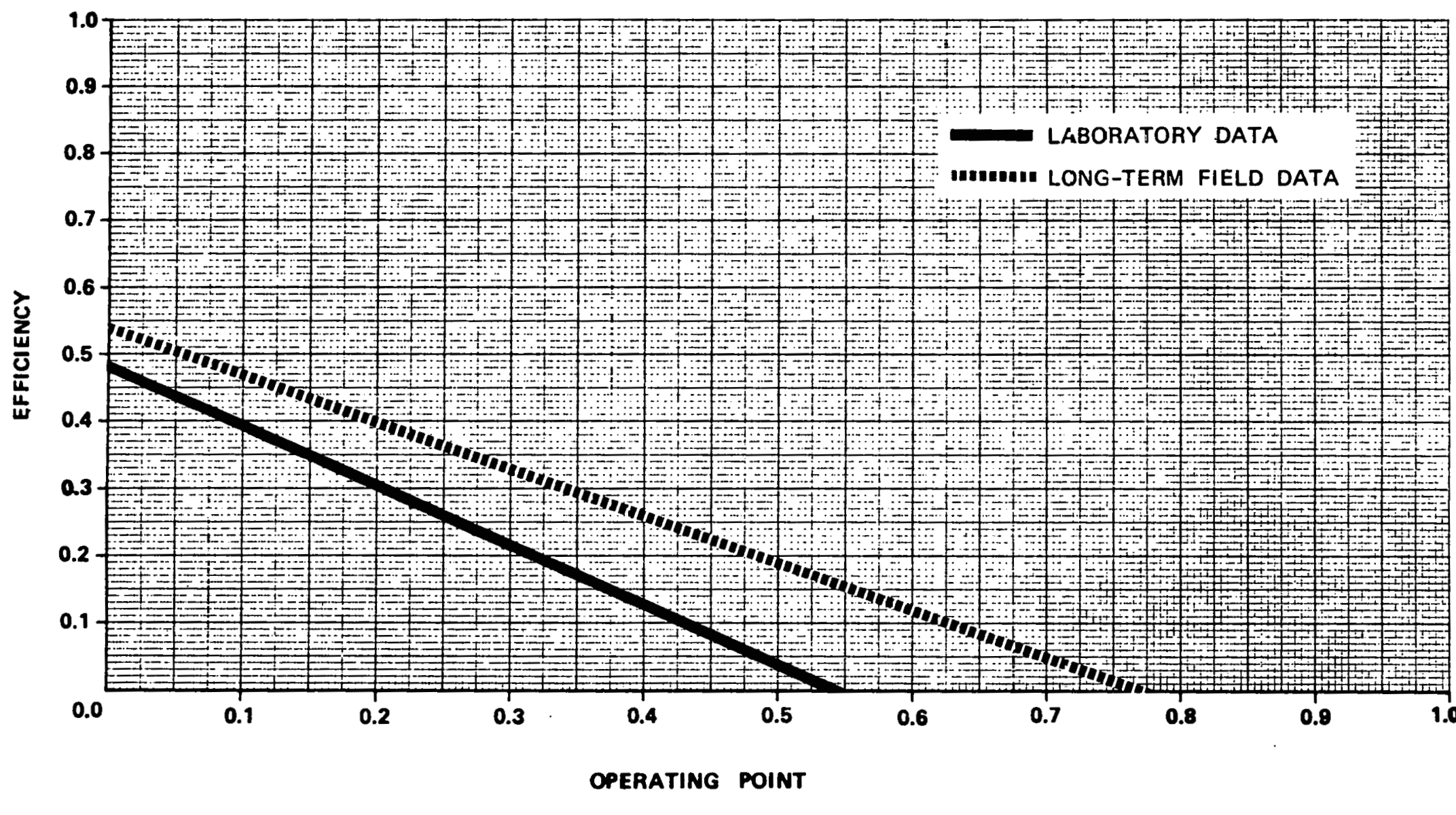

FIgure 3.2.1-2 Solaron Dufffeld Collector Efflclency Curves 
For information purposes the data associated with Figure 3.2.1-2 is as follows:

Single panel laboratory data

$$
F_{R}(\tau \alpha)=0.476 \quad F_{R} U_{L}=-0.856
$$

Long-term field data

$$
F_{R}(\tau \alpha)=0.536 \quad F_{R} U_{L}=-0.693
$$

Table 3.2.1-2 presents data comparing the monthly measured values of solar energy collected with the predicted performance determined from the long-term regression curve and the laboratory single panel efficiency curve. The predictions were derived by the following procedure:

1. The instantaneous operating points were computed using Equation (3).

2. The instantaneous efficiency was computed using Equation (4) with the operating point computed in Step 1 above for:

a. The long-term linear regression curve for collector array efficiency

b. The laboratory single panel collector efficiency curve

3. The efficiencies computed in Steps $2 a$ and $2 b$ above were multiplied by the measured solar energy available when the collectors were operational to give two predicted values of solar energy collected. 
TABLE $3.2 .1-2$

ENERGY GAIN COMPARISONN

(ANNUAL)

SITE: SOLARON DUFFIELD

DUFFIELD, VIRGINIA

\begin{tabular}{|c|c|c|c|}
\hline \multirow[b]{2}{*}{ Month } & \multirow{2}{*}{$\begin{array}{l}\text { Collected } \\
\text { Solar Energy } \\
\text { (Million Btu) }\end{array}$} & \multicolumn{2}{|c|}{ Error } \\
\hline & & $\begin{array}{l}\text { Field Derived } \\
\text { Long-Term }\end{array}$ & $\begin{array}{l}\text { Laboratory } \\
\text { Single Panel }\end{array}$ \\
\hline Nov 79 & 3.840 & 0.103 & 0.288 \\
\hline Dec 79 & 4.053 & 0.106 & 0.315 \\
\hline Feb 80 & 4.6510 & 0.233 & 0.535 \\
\hline Average & 4.181 & 0.139 & 0.388 \\
\hline
\end{tabular}


The error data in Table 3.2.1-2 were computed from the differences between the measured and predicted values of solar energy collected according to the equation:

$$
\text { Error }=(A-P) / P
$$

where $\begin{aligned} A & =\text { Measured solar energy collected } \\ P & =\text { Predicted solar energy collected }\end{aligned}$

The computed error is then an indication of how well the particular prediction curve fitted the reality of dynamic operating conditions in the field.

The values of "Collected Solar Energy" given in Table 3.2.1-2 are not necessarily identical with the values of "Collected Solar Energy" given in Table 3.2.1-1. Any variations are due either to differences in the data base or to the differences in data processing between the software programs used to generate the monthly performance assessment data and the component level collector analysis program. These data are shown in Table 3.2.1-2 only because they form the references from which the error data given in the table are coimputed.

The data from Table 3.2.1-2 illustrates that, for the Solaron Duffield site, the average error computed from the difference between the measured solar energy collected and the predicted solar energy collected based on the field derived long-term collector array efficiency curve was 13.9 percent. For the curve derived from the laboratory single panel data, the error was 38.8 percent. Thus the long-term collector array efficiency curve gives significantly better results than the laboratory single panel curve.

A histogram of collector array operating points illustrates the distribution of instantaneous values as determined by Equation (3) for the 
entire month. The histogram was constructed by computing the instantaneous operating point value from site instrumentation measurements at the regular data system intervals througout the month, and counting the number of values within contiguous intervals of width 0.01 from zero to unity. The operating point histogram shows the dynamic range of collector operation during the month from which the midpoint can be ascertained. The average collector array efficiency for the month can then be derived by projecting the midpoint value to the appropriate efficiency curve and reading the corresponding value of efficiency.

Another characteristic of the operating point histogram is the shifting of the distribution along the operating point axis. This can be explained in terms of the characteristics of the system, the climatic factors of the site, i.e., incident solar energy and ambient temperature, and the method of system operation. Figure 3.2.1-3 shows two histograms that ilustrate a typical winter month (February) and a typical transitional month (November) operation. The approximate average operating point for February is at 0.16 and for November 0.08. In terms of Equation (3) it can be seen that, as the operating point becomes larger, the collector array efficiency decreases.

Table 3.2.1-1 presents the monthly values of incident solar energy, operational. incident solar energy, and collected solar energy from the six month performance period. The collector array efficiency and operational collector array efficiency were computed for each month using Equations (1) and (2). On the average the operational collector array efficiency exceeded the collector array efficiency, which included the affect of the control system, by 45 percent.

Additional information concerning collector array analysis in general may be found in Reference [6]. The material in the reference describes the detailed collector array analysis procedures and presents the results of analyses performed on numerous collector array installations across the United States. 
SOLARON DUFFJELO

COLLECTOR TYPE: SOLARCN
DUFFTFLD， VA

COLLECTOR MODEL: 2000 SFRIES

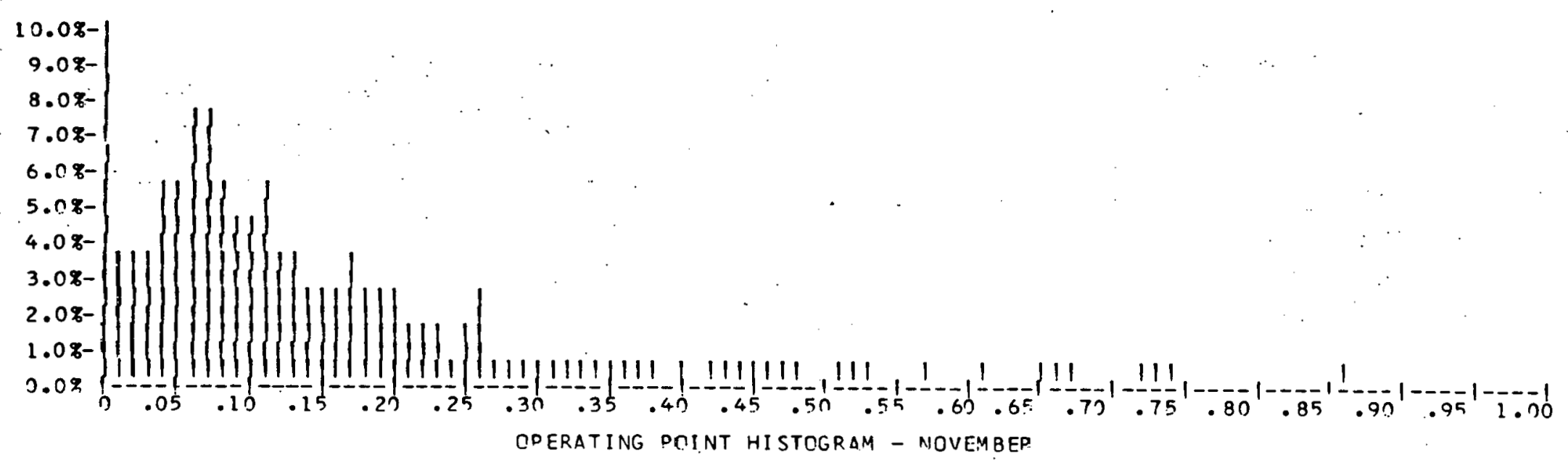

$\stackrel{\omega}{\omega}$

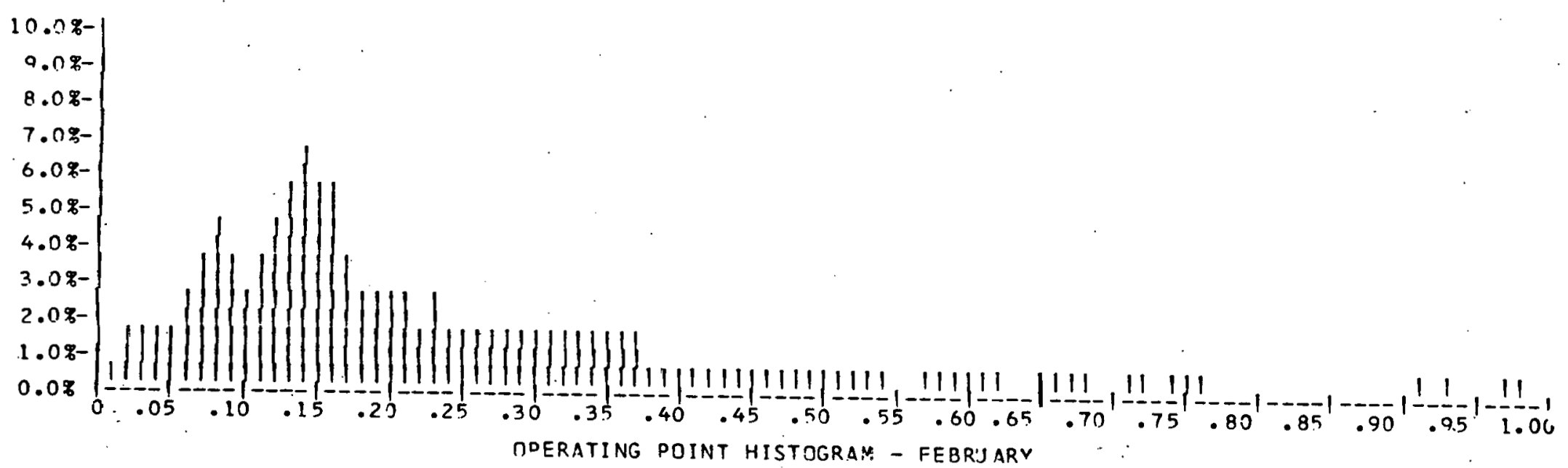
ABC ISSA = IINLET TEMP FAMB TENT TEMDIITNSOLATIOV DER, F - HD - SOFT/RTU
ORD INATE = PERCENT OF TOTAL OCCURRENCES

Figure 3.2.1-3 Solaron Duffield Operating Point Histograms for

- Typicar Winter and Transitional Months 


\subsubsection{Storage Subsystem}

Storage subsystem performance is described by comparison of energy to storage, energy from storage and change in stored energy. The ratio of the sum of energy from storage and change in stored energy to energy to storage is defined as storage efficiency, $n_{s}$. This relationship is expressed in the equation

$$
n_{s}=\left(\Delta Q+Q_{s o}\right) / Q_{s i}
$$

where:

$\Delta Q=$ Change in stored energy. This is the difference in the estimated stored energy during the specified reporting period, as indicated by the relative temperature of the storage medium (either positive or negative value)

$Q_{\text {so }}=$ Energy from storage. This is the amount of energy extracted by the load subsystem from the primary storage medium

$Q_{s i}=$ Energy to storage. This is the amount of energy (both solar and auxiliary) delivered to the primary storage medium

Evaluation of the system storage performance under actual system operation and weather conditions can be performed using the parameters defined above. The utility of these measured data in evaluation of the overall storage design can be illustrated in the following discussion. 
Table 3.2.2-1 summarizes the storage subsystem performance during the report period.

During the six month period an approximate total of $16.56 \mathrm{mill}$ ion Btu was delivered to storage and 16.43 million Btu were extracted for support of the space heating load. During this period the net change in stored energy was 0.05 million Btu, which leads to an overall storage efficiency of 0.96 and a total heat loss from storage of $0.08 \mathrm{million} \mathrm{Btu.} \mathrm{The} \mathrm{average} \mathrm{tem-}$ perature of storage was $80^{\circ} \mathrm{F}$.

It will be noted that during the month of November considerably more heat was removed from storage than was put into storage. This was brought about by a damper malfunction which caused the house return air to pass through storage when the system was operating in the auxiliary heating mode. Thus the auxiliary heating system was adding heat to storage. 
TABLE 3.2.2-1

STORAGE SUBSYSTEM PERFORMANCE

\begin{tabular}{|c|c|c|c|c|c|}
\hline Month & $\begin{array}{c}\text { Energy To } \\
\text { Storage } \\
\text { (Millian Btu) }\end{array}$ & $\begin{array}{l}\text { Energy From } \\
\text { Storage } \\
\text { (Million Btu) }\end{array}$ & $\begin{array}{l}\text { Change In } \\
\text { Stored } \\
\text { Energy } \\
\text { (Million Btu) }\end{array}$ & $\begin{array}{l}\text { Storage } \\
\text { Efficiency }\end{array}$ & $\begin{array}{c}\text { Storage } \\
\text { Average } \\
\text { Temperature } \\
\left({ }^{\circ} \mathrm{F}\right)\end{array}$ \\
\hline Oct 79 & 2.11 & 1.28 & 0.18 & 0.69 & 77 \\
\hline Nov 79 & 2.66 & 4.93 & -0.17 & $1.79 *$ & 87 \\
\hline Dec 79 & 3.61 & 3.25 & 0.01 & 0.90 & 77 \\
\hline Jan 80 & 1.00 & 0.71 & -0.05 & 0.65 & 77 \\
\hline Feb 80 & 3.59 & 3.26 & -0.03 & 0.90 & 79 \\
\hline $\operatorname{Mar} 80$ & 3.59 & 3.00 & 0.01 & 0.84 & 83 \\
\hline Total & .16 .56 & .16 .43 & 0.05 & -- & -- \\
\hline Average & 2.76 & 2.74 & -0.01 & 0.96 & 80 \\
\hline
\end{tabular}

*This number is greater than 1.00 due to the damper leakage problem discussed in the text. 


\subsubsection{Hot Water Subsystem}

The performance of the hot water subsystem is described by comparing the amount of solar energy supplied to the subsystem with the energy required to satisfy the total hot water load. The energy required to satisfy the total load consists of both solar energy and auxiliary thermal energy.

The performance of the Solaron Duffield hot water subsystem is presented in Table 3.2.3-1. The value for auxiliary energy supplied in Table 3.2.3-1 is the gross energy supplied to the auxiliary system. The value of auxiliary energy supplied multiplied by the auxiliary system efficiency gives the auxiliary thermal energy actually delivered to the load. The difference between the sum of auxiliary thermal energy plus solar energy and the hot water load is equal to the thermal (standby) losses from the hot water subsystem.

The measured solar fraction in Table 3.2.3-1 is an average weighted value for the month based on the ratio of solar energy in the hot water tank to the total energy in the hot water tank when a demand for hot water exists. This value is dependent on the daily profile of hot water usage. It does not represent the ratio of solar energy supplied to the sum of solar plus auxiliary thermal energy supplied shown in the Table.

For the six month period from October 1979 through March 1980, the solar energy system supplied a total of 2.90 million Btu to the hot water subsystem. However, the hot water subsystem itself effectively delivered $1.93 \mathrm{million}$ Btu to the hot water load. The difference represents losses attributable to the preheat tank and its associated plumbing. The total hot water load for this period was $5.71 \mathrm{million} \mathrm{Btu,} \mathrm{and} \mathrm{the} \mathrm{weighted}$ average monthly solar fraction was 28 percent. 
TABLE $3.2 .3-1$

HOT WATER SUBSYSTEM PERFORMANCE

\begin{tabular}{|c|c|c|c|c|c|c|c|c|}
\hline \multirow[b]{2}{*}{ Month } & \multicolumn{4}{|c|}{ Hot Water Parameters } & \multicolumn{3}{|c|}{$\begin{array}{l}\text { Energy Consumed } \\
(M=11 \text { ion } \mathrm{Btu})\end{array}$} & \multirow{2}{*}{$\begin{array}{l}\text { Weighted } \\
\text { Solar } \\
\text { Fraction } \\
\text { (Percent) }\end{array}$} \\
\hline & $\begin{array}{l}\text { Load } \\
\text { (Mililion Btu) }\end{array}$ & $\begin{array}{c}\text { GaTions } \\
\text { Used }\end{array}$ & Temperatures $\left({ }^{\circ} \mathrm{F}\right)$ & $\begin{array}{l}\left.\text { res ( }{ }^{\circ} \mathrm{F}\right) \\
\text { Delivery }\end{array}$ & Solar & $\begin{array}{l}\text { Auxitiary } \\
\text { Thermal }\end{array}$ & Auxiliary & \\
\hline Oct 79 & 0.67 & 1,379 & 66 & 128 & 0.38 & 0.73 & 0.73 & 26 \\
\hline Nov 79 & 0.73 & 1,379 & 62 & 126 & 0.51 & 0.72 & 0.72 & 31 \\
\hline $\operatorname{Dec} 79$ & 1.02 & 1,914 & 56 & 126 & 0.57 & 1.00 & 1.00 & 27 \\
\hline Jan 80 & 1.05 & 1,817 & 53 & 125 & 0.23 & 1.18 & 1.18 & 15 \\
\hline Feb 80 & 1.08 & 1,763 & 50 & 125 & 0.62 & 0.94 & 0.94 & 33 \\
\hline Mar 80 & 1.16 & 1,922 & 52 & 125 & 0.59 & 1.01 & 1.01 & 34 \\
\hline Total & 5.71 & 10,174 & -- & -- & 2.90 & 5.58 & 5.58 & -- \\
\hline Average & 0.95 & 1,696 & 57 & 126 & 0.48 & 0.93 & 0.93 & 28 \\
\hline
\end{tabular}


The monthly average hot water load during the reporting period was 0.95 million Btu. This is based on an average daily consumption of 56 gallons, delivered at an average temperature of $126^{\circ} \mathrm{F}$ and supplied to the system at an average temperature of $57^{\circ} \mathrm{F}$. The temperature of the supply water ranged from a low of $50^{\circ} \mathrm{F}$. in February to a high of $66^{\circ} \mathrm{F}$ in october.

Each month an average of 0.32 mlllion Btu of solar energy from the preheat tank and 0.93 million Btu of auxiliary thermal (electrical) energy were supplied to support the hot water load. Since the average monthly hot water load was 0.95 million Btu, an average of 0.30 million Btu was lost from the hot water tank each month. In addition, an average of 0.02 million Btu of operating energy was required to support the hot water subsystem each month. 


\subsubsection{Space Heating Subsystem}

The performance of the space heating subsystem is described by comparing the amount of solar energy supplied to the subsystem with the energy required to satisfy the total space heating load. The energy required to satisfy the total load consists of both solar energy and auxiliary thermal energy. The ratio of solar energy supplied to the load to the total load is defined as the heating solar fraction. The calculated heating solar fraction is the indicator of performance for the subsystem because it defines the percentage of the total space heating load supported by solar energy.

The performance of the Solaron Duffield space heating subsystem is presented in Table 3.2.4-1. For the six month period from October 1979 through March 1980, the solar energy system supplied a measured total of 20.22 million Btu to the space heating load. The total measured heating load for this period was 51.91 million Btu, and the average monthly solar fraction was 39 percent.

During the six month reporting period a total of 16.55 million Btu of auxiliary energy was consumed by the space heating subsystem when it was operating in the various auxiliary heating modes. Of this total, 13.81 million Btu were consumed by the heat pump compressor and 2.74 million Btu were consumed by the heat strips. Since 44.61 million Btu were added to the auxiliary heating system by the heat pump, the average COP of the heat pump was approximately 3.23. This is in contrast to the average COP of approximately 1:63 for the entire off-peak system. The average overall system COP of 1.63 is based on a comparison of the total amount of power consumed by the heat pump compressor and pump P2 versus the total energy delivered to the auxiliary system at $H \times 2$ (reference Figure 2-1). As such, it is a more accurate indicator of the auxiliary heat pump system performance because it represents the actual ratio of energy sought to energy that costs. Power unnecessarily consumed by efther pumps $P 2$ and $P 3$ or the heat pump compressor due to control system or other problems is included, so the average system COP represents all phases of system operation. 
TABLE 3.2.4-1

HEATING SUBSYSTEM PERFORMANCE

\begin{tabular}{|c|c|c|c|c|c|c|c|}
\hline \multirow[b]{2}{*}{ Month } & \multicolumn{3}{|c|}{ Heating Parameters } & \multicolumn{3}{|c|}{$\begin{array}{c}\text { Energy Consumed } \\
\text { (Million Btu) }\end{array}$} & \multirow{2}{*}{$\begin{array}{l}\text { Measured } \\
\text { Solar } \\
\text { Fraction } \\
\text { (Percent) }\end{array}$} \\
\hline & $\begin{array}{l}\text { Load } \\
\text { (Mtllion Btu) }\end{array}$ & $\begin{array}{l}\text { Tempera } \\
\text { Buifding }\end{array}$ & $\begin{array}{l}\left.\text { s( }{ }^{\circ} F\right) \\
\text { Outdoor }\end{array}$ & Solar & $\begin{array}{l}\text { Auxiliary } \\
\text { :hermal }\end{array}$ & Auxiliary & \\
\hline Oct 79 & 4.35 & 73 & 52 & 1.65 & 6.20 & 2.28 & 38 \\
\hline Nov 79 & 9.00 & 73 & 46 & 5.93 & 4.90 & 2.30 & 66 \\
\hline Dec 79 & 10.53 & 73 & 36 & 3.99 & 9.11 & 3.39 & 38 \\
\hline Jan 80 & 9.25 & 73 & 39 & 1.00 & 11.20 & 3.60 & 11 \\
\hline Feb 80 & 10.97 & 72 & 31 & 4.29 & 9.02 & 3.05 & 39 \\
\hline Mar 80 & 7.81 & 72 & 42 & 3.36 & 6.92 & 1.93 & 43 \\
\hline Total & 51.91 & -- & -- & 20.22 & 47.35 & 16.55 & -- \\
\hline Average & 8.65 & 73 & 41 & 3.37 & 7.89 & 2.76 & $39 *$ \\
\hline
\end{tabular}

*Average solar fraction is the ratio of total solar energy to total load. 


\section{OPERATING ENERGY}

Operating energy for the Solaron Duffield Solar Energy System is defined as the energy required to transport solar energy to the point of use. Total operating energy for this system consists of energy collection and storage subsystem operating energy, hot water subsystem operating energy and space heating subsystem operating energy. Operating energy is electrical energy that is used to support the subsystems without affecting the ir thermal state. Measured monthiy values for subsystem operating energy are presented in Table 4-1.

Total system operating energy for the Solaron Duffield Solar Energy System is that electrical energy required to operate the blowers in the ECSS loop (B1) and the air distribution duct (B2), the pumps in the DHW subsystem (P1) and the auxiliary heat punp system (P2 and P3), and the heat pump outside fan. These are shown as EP100, EP400, EP301, EP404 and EP403, respectively, in Figure 2-1. Although additional electrical energy is required to operate the three motor driven dampers and the control system for the installation, it is not included in this report. These devices are not monitored for power consumption and the power they consume is inconsequential when compared to the fan and pump motors.

During the six month reporting period, a total of 11.58 million Btu (3393 kWh) of operating energy was consumed. However, this includes the energy required to operate the blower in the air distribution duct and the pump and outside fan in the heat pump system, and that energy would be required whether or not the solar energy system was being utilized for space heating. Therefore, the energy consumed by these devices is not considered to be solar peculiar operating energy, even though it is included as part of the space heating subsystem operating energy. 
TA3LE 4-1

OPERATING ENERGY

\begin{tabular}{|l|c|c|c|c|}
\hline Month & $\begin{array}{c}\text { ECSS } \\
\text { Operating Energy } \\
\text { (Million Btu) }\end{array}$ & $\begin{array}{c}\text { Hot Water } \\
\text { Operating Energy } \\
\text { (Million Btu) }\end{array}$ & $\begin{array}{c}\text { Space Heating } \\
\text { Operating Erergy } \\
\text { (Million Btu) }\end{array}$ & $\begin{array}{c}\text { Total System } \\
\text { Operating Energy } \\
\text { (Million Btu) }\end{array}$ \\
\hline Oct 79 & 0.080 & 0.019 & 1.549 & 1.648 \\
Nov 79 & 0.104 & 0.028 & 0.629 & 0.761 \\
Dec 79 & 0.120 & 0.028 & 2.111 & 2.259 \\
Jan 80 & 0.040 & 0.069 & 2.512 & 2.561 \\
Feb 80 & 0.112 & 0.024 & 2.263 & 2.399 \\
Mar 80 & 0.096 & 0.024 & 1.828 & 1.948 \\
\hline Tota1 & 0.552 & 0.132 & 10.892 & 11.576 \\
\hline Average & 0.092 & 0.022 & 1.815 & 1.929 \\
\hline
\end{tabular}


A total of 0.68 million Btu (199 kWh) of operating energy was required to support the pump and fan that are unique to the solar energy system during the reporting period. Of this total, 0.55 million Btu were allocated to the Energy Collection and Storage Subsystem (ECSS) and $0.13 \mathrm{mil}$ lion Btu were allocated to the DHW Subsystem. Since a measured 22.15 million Btu of solar energy was delivered to system loads during the reporting period, a total of 0.03 million Btu ( $9 \mathrm{kWh})$ of operating energy was required for each one million Btu of solar energy delivered to the system loads. 


\section{ENERGY SAVINGS}

Solar energy system savings are realized whenever energy provided by the solar energy system is used to meet system demands which would otherwise be met by auxiliary energy sources. The operating energy required to provide solar energy to the load subsystems is subtracted from the solar energy contribution, and the resulting energy savings are adjusted to reflect the coefficient of performance (COP) of the auxiliary source being supplanted by solar energy.

The Solaron Dufficld Solar [nergy System has a heat pump for auxiliary space heating purposes. However, the heat pump is not used as a stand-alone unit, but rather in conjunction with an off-peak storage tank and associated hardware. As discussed in the Space Heating Subsystem section, the average COP for the overall heat pump system (not including the electrical strip heaters) was approximately 1.63 for the reporting period. Auxiliary energy for the heat strips and hot water heating is also provided by electricity and the COP for both the strips and hot water heating element is considered to be 1.0 for computational purposes.

Energy savings for the six month reporting period are presented in Table $5-1$. During this time the system realized a gross electrical energy savings of $16.83 \mathrm{million} \mathrm{Btu}$, which is the amount of solar energy supplied to the hot water subsystem and space heating subsystem (with appropriate COP adjustment). Since 0.13 million Btu were required to operate the hot water subsystem recirculation pump, the net savings for the hot water subsystem amounted to 1.80 million Btu. The net savings for the space heating subsystem, which is not charged with any operating energy deduction, totaled 14.90 million Btu. The ECSS blower consumed 0.55 million Btu of operating energy, so the net electrical energy savings for the entire solar energy system were 16.15 million Btu $(4732 \mathrm{kWh})$, or approximately 3 barrels of oil. 
TABLE 5-1

\section{ENERGY SAVINGS}

\begin{tabular}{|c|c|c|c|c|c|c|}
\hline \multirow[b]{2}{*}{ Month } & \multicolumn{2}{|c|}{$\begin{array}{c}\text { Electrical } \\
\text { Energy Savings } \\
\text { (Million Btu) }\end{array}$} & \multirow{2}{*}{$\begin{array}{l}\text { ECSS } \\
\text { Operating } \\
\text { Energy } \\
\text { (Million Btu) }\end{array}$} & \multicolumn{2}{|c|}{$\begin{array}{c}\text { Net } \\
\text { Electrical Energy } \\
\text { Savinas }\end{array}$} & \multirow{2}{*}{$\begin{array}{l}\text { Fossil } \\
\text { Equivalent } \\
\text { At Source } \\
\text { (Million Btu) }\end{array}$} \\
\hline & $\begin{array}{c}\text { Hot } \\
\text { Water }\end{array}$ & $\begin{array}{l}\text { Space } \\
\text { Heating }\end{array}$ & & (Witrion Btu) & $(\mathrm{kWh})$ & \\
\hline Oct 79 & 0.192 & 1.414 & 0.080 & 1.526 & 447 & 5.087 \\
\hline Nov 79 & 0.258 & 4.082 & 0.104 & 4.236 & 1,241 & 14.120 \\
\hline Dec 79 & 0.320 & 2.752 & 0.120 & 2.952 & 865 & 9.840 \\
\hline Jan 80 & 0.183 & 0.691 & 0.040 & 0.834 & 244 & $2.780^{\circ}$ \\
\hline Feb 80 & 0.413 & 3.388 & 0.112 & 3.689 & 1,081 & 12.297 \\
\hline Mar 80 & 0.432 & 2.575 & 0.096 & 2.911 & 853 & 9.703 \\
\hline Total & 1.798 & 14.902 & 0.552 & 16.148 & 4,731 & 53.827 \\
\hline Average & 0.300 & 2.484 & 0.092 & 2.69 & 789. & 8.971 \\
\hline
\end{tabular}


It should be noted that all values relating to space heating savings are based only on the measured solar energy contribution to the space heating load. There are some transport and storage losses present in this solar energy system, but they were not considered in any savings computations. 


\subsection{MAINTENANCE}

This section provides a summary of all known maintenance visits made to the Solaron Duffield site from the time it went on line until the closing of the data assessment period.

December 5, 1979

- Fixed all control problems and replaced stripped gear on damper.

January 16,1980

- Scalcd all duct leak.s. 


\section{SUMMARY AND CONCLUSIONS}

The following paragraphs provide a brief summary of all pertinent parameters for the Solaron Duffield Solar Energy System for the period from October 1979 to March 1980. A more detailed discussion can be found in the applicable preceding sections.

During the reporting period, the measured daily average incident insolation in the plane of the collector array was $793 \mathrm{Btu} / \mathrm{Ft}^{2}$. This was 34 percent below the long-term daily average of 1,207 Btu/Ft². During the same period the measured average outdoor ambient temperature was $41^{\circ} \mathrm{F}$. This was five degrees below the long-term average of $46^{\circ} \mathrm{F}$. As a result 4,392 heating degree-days were accumulated, as compared to the long-term average of 3,492 heating degree-days.

The solar energy system satisfied 39 percent of the total measured load (hot water plus space heating) during the six month reporting period. This did not agree with the expected value of 24 percent for the reporting period. The exact cause for the variation is suspected to be due to computational variations between measured conditions and the f-Chart assumptions used in deriving the expected value.

A total of 62.03 million Btu of incident solar eneray was measured in the plane of the collector array during the reporting period. The system collected 23.45 million Btu of the available energy, which represents a collector array efficiency of 38 percent. During the periods when the collector array was active, a total of 42.70 million Btu was measured in the plane of the collector array. Therefore, the operational collector efficiency was 55 percent.

During the reporting period a total of 16.56 million Btu of solar energy was delivered to the storage bin. During this same time 16.43 million Btu were removed from storage for support of the space heating load. During this period the net change in stored energy was 0.05 million Btu and 0.08 million Btu were lost from storage. The average storage efficiency was 0.96 and the average temperature was $80^{\circ} \mathrm{F}$. 
The hot water load for the six month reporting period was 5.71 million Btu. A total of 1.93 million Btu of solar energy and 5.58 million Btu of auxiliary energy were applied to the hot water load, which represents a weighted hot.water solar fraction of 28 percent. The average daily consumption of hot water was 56 gallons, delivered at an average temperature of $126^{\circ} \mathrm{F}$. A total of 2.77 million Btu was lost from the hot water tank, the preheat tank, and the subsystem piping during the reporting period.

The measured space heating load was 51.91 million Btu for the reporting period, and the heating solar fraction was 39 percent. During the heating season a total of 20.22 million Btu of measured solar energy and 31.69 million Btu of auxiliary thermal energy were actually delivered to the space heating load, and this energy maintained an average building temperature of $73^{\circ} \mathrm{F}$. However, a total of 47.35 million Btu of auxiliary thermal energy was actually added to the space heating subsystem by the compressor and heat strips during the primary heating season when the system was operating in a defined heating mode.

A total of 0.68 million Btu, or $199 \mathrm{kWh}$, of electrical operating energy was required to support the solar energy system during the six month reporting period. This does not include the electrical energy required to operate the fan, pump or heat pump in the auxiliary system. These would be required for operation of the space heating subsystem regardless of the presence of the solar energy system.

Gross electrical energy savings for the six month reporting period were 16.83 million Btu. However, when the 0.68 million Btu of electrical operating energy is taken into account, the net electrical energy savings were 16.15 million Btu, or $4,732 \mathrm{kWh}$, or approximately 3 barrels of oil. If a 30 percent efficiency is assumed for power generation and distribution, then the net electrical energy savings translate into a savings of 53.83 million Btu in generating station fuel requirements or approximately 9 barrels of oil. It should also be noted that the electrical energy savings are based only on the measured amount of solar energy delivered to the space heating subsystem. 
8. REFERENCES

1. DOE/NASA CR-161190, Installation Package for the Solaron Solar Subsystem, Apri1, 1979.

2. E. Streed, etc. al., Thermal Data Requirements and Performance Evaluation Procedures for the National Solar Heating and Cooling Demonstration Program, NBSIR-76-1137, NationaT Bureau of Standards, Washington, August, 1976.

3. J. T. Smok, V. S. Sohoni, J. M. Nash, "Processing of Instrumented Data for the National Solar Heating and Cooling Demonstration Program," Conference on Performance Monitoring Techniques for Evaluation of Solar Heating and Cooling Sytems, Washington, D.C., Apri1, 1978.

4. ASHRAE Standard 93-77, Methods of Testing to Determine the Thermal Performance of Solar Collectors, The American Society of Heating, Refrigeration and Air Conditioning Engineers, Inc., New York, NY, 1977.

5. ASHRAE Standard 94-77, Methods of Testing Thermal Storage Devices Based on Thermal Performiance, The American Society of Heating, Refrigeration and Air Conditioning Engineers, Inc., New York, NY, 1977.

6. McCumber, W. H. Jr., "Collector Array Performance for Instrumented Sites of the National Solar Heating and Cooling Demonstration Program," published and distributed at the 1979 Solar Update Conference.

7. Beckman, William A.; Klein, Sanford A; Duffie, John A; Solar Heating Design by the f-Chart Method, Wiley Interscience, New York, NY, 1977 . 
APPENDIX A

DEFINITION OF PERFORMANCE FACTORS AND SOLAR TERMS

A-1 


\section{APPENDIX A \\ DEFINITION OF PERFORMANCE FACTORS AND SOLAR TERMS}

\section{ENERGY COLLECTION AND STORAGE SUBSYSTEM}

The Energy Collection and Storage Subsystem (ECSS) is composed of the collector array, the primary storage medium, the transport loops between these, and other components in the system design which are necessary to mechanize the collector and storage equipment.

- INCIDENT SOLAR ENERGY (SEA) is the total insolation available on the gross collector array area. This is the area of the collector array energy-receiving aperture, including the framework which is an integral part of the collector structure.

- AMBIENT TEMPERATURE (TA) is the average temperature of the outdoor environment at the site.

- ENERGY TO LOADS (SEL) is the total thermal energy transported from the ECSS to all load subsystems.

- AUXILIARY THERMAL ENERGY TO ECSS (CSAUX) is the total auxitiary supplied to the ECSS, including auxll lary energy added to the storage tank, heating devices on the collectors for freezeprotection, etc.

- ECSS OPERATING ENERGY (CSOPE) is the critical operating energy required to support the ECSS heat transfer loops. 


\section{COLLECTOR ARRAY PERFORMANCE}

The collector array performance is characterized by the amount of solar energy collected with respect to the energy available to be collected.

- INCIDENT SOLAR ENERGY (SEA) is the total insolation available on the gross collector array area. This is the area of. the collector array energy-receiving aperture, including the framework which is an integral part of the collector structure.

- OPERATIONAL INCIDENT ENERGY (SEOP) is the amount incident solar energy on the collector array during the time that the collector loop is active (attempting to collect energy).

- COLLECTED SOLAR ENERGY (SECA) is the thermal energy removed from the collector array by the energy transport medium.

- COLLECTOR ARRAY EFFICIENCY (CAREF) is the ratio of the energy collected to the total solar energy incident on the collector array. It should be emphasized that this efficiency factor is for the collector array, and available energy includes the incident energy on the array when the collector loop is inactive. This efficiency must not be confused with the more common collector efficiency figures which are determined from instantaneous test data obtained during steady state operation of a single collector unit. These efficiency figures are often provided by collector manufacturers or presented in technical journals to characterize the functional capability of a particular collector design. In general, the collector panel maximum efficiency factor will be significantly higher than the collector array efficiency reported here. 


\section{STORAGE PERFORMANCE}

The storage performance is characterized by the relationships among the energy delivered to storage, removed from storage, and the subsequent change in the amount of stored energy.

- ENERGY TO STORAGE (STEI) is the amount of energy, both solar and auxiliary, delivered to the primary storage medium.

- ENERGY FROM STORAGE (STEO) is the amount of energy extracted by the load subsystems from the primary storage medium.

- CHANGE IN STORED ENERGY (STECH) is the difference in the estimated stored energy during the specified reporting period, as indicated by the rèlative temperature of the storage medium (either positive or negative value).

- STORAGE AVERAGE TEMPERATURE (TST) is the mass-weighted average temperature of the primary storage medium.

- STORAGE EFFICIENCY (STEFF) is the ratio of the sum of the energy removed from storage and the change in stored energy to the energy delivered to storage. 
HOT WATER SUBSYSTEM

The hot water subsystem is characterized by a complete accounting of the energy flow to and from the subsystem, as well as an accounting of internal energy. The energy into the subsystem is composed of auxiliary electrical or fossil fuel, solar energy, and the operating energy for the subsystem. In addition, the solar fraction for the subsystem is tabulated. The load of the subsystem is tabulated and used to compute the estimated electrical and fossil fuel savings of the subsystem. The load of the subsystem is further identified by tabulating the supply water temperature, and the outlet hot water temperature, and the total hot water consumption.

- HOT WATER LOAD (HWL) is the amount of energy required to heat the amount of hot water demanded at the site from the incoming temperature to the desired outlet temperature.

- SOLAR FRACTION OF LOAD (HWSFR) is the percentage of the load demand which is, supported by solar energy.

- SOLAR ENERGY USED (HWSE) is the amount of solar energy supplied to the not water subsystem.

- OPERATING ENERGY (HWOPE) is the amount of electrical energy required to support the subsystem, (e.g., fans, pumps, etc.) and which is not intended to affect directly the thermal state of the subsystem.

- AUXILIARY THERMAL USED (HWAT) is the amount of energy supplied to the major components of the subsystem in the form of thermal energy in a heat transfer fluid, or its equivalent. This term also includes the converted electrical and fossil fuel energy supplied to the subsystem. 
- AUXILIARY ELECTRICAL FUEL (HWAE) is the amount of electrical energy supplied directly to the subsystem.

- ELECTRICAL ENERGY SAVINGS (HWSVE) is the estimated difference between the electrical energy requirements of an al ternative conventional system (carrying the full load) and the actual electrical energy required by the subsystem.

- SUPPLY WATER TEMPERATURE (TSW) is the average inlet temperature. of the water supplied to the subsystem.

- AVERAGE HOT WATER TEMPERATURE (THW) is the average temperature of the outlet water as it is supplied from the subsystem to the load.

- HOT WATER USED (HWCSM) is the volume of water used. 
The space heating subsystem is characterized by performance factors accounting for the complete energy flow to and from the subsystem. The average building temperature and the average ambient temperature are tabulated to indicate the relative performance of the subsystem in satisfying the space heating load and in controlling the temperature of the conditioned space.

- SPACE HEATING LOAD (HL) is the sensible energy added to the air in the building.

- SOLAR FRACTION OF LOAD (HSFR) is the fraction of the sensible energy added to the air in the building derived from the solar energy system.

- 'SOLAR ENERGY USED (HSE) is the amount of solar energy supplied to the space heating subsystem.

OPERATING ENERGY (HOPE) is the amount of electrical energy required to support the subsystem, (e.g., fans, pumps, etc.) and which is not intended to affect directly the thermal state of the subsystem.

- AUXILIARY THERMAL USED (HAT) is the amount of energy supplied to the major components of the subsystem in the form of thermal energy in a heat transfer fluid or its equivalent. This term also includes the converted electrical and fossil fuel energy supplied to the subsystem.

- AUXILIARY ELECTRIC FUEL (HAE) is the amount of electrical energy supplied directly to the subsystem.

- ELECTRICAL ENERGY SAVINGS (HSVE) is the estimated difference between the electrical energy requirements of an alternative conventional system (carrying the full load) and the actual electrical energy required by the subsystem. 
- BUILDING TEMPERATURE (TB) is the average heated space dry bulb temperature.

- AMBIENT TEMPERATURE (TA) is the average ambient dry bulb temperature at the site. 
The environmental summary is a collection of the weather data which is generally instrumented at each site in the program. It is tabulated in this data report for two purposes--as a measure of the conditions prevalent during the operation of the system at the site, and as an historical record of weather data for the vicinity of the site.

- TOTAL INSOLATION (SE) is accumulated total incident solar energy upon the gross collector array measured at the site.

- AMBIENT TEMPERATURE (TA) is the average temperature of the environment at the site.

- WIND DIRECTION (WDIR) is the average direction of the prevailing wind.

- WIND SPEED (WIND) is the average wind speed measured at the site.

- DAYTIME AMBIENT TEMPERATURE (TDA) is the temperature during the period from three hours before solar noon to three hours after solar noon. 
APPENDIX B

SOLAR ENERGY SYSTEM PERFORMANCE EQUATIONS FOR

SOLARON DUFFIELD 


\section{APPENDIX B}

\section{SOLAR ENERGY SYSTEM PERFORMANCE EQUATIONS FOR}

SOLARON DUFFIELD

\section{INTRODUCTION}

Solar energy system performance is evaluated by performing energy balance calculations on the system and its major subsystems. These calculations are based on physical measurement data taken from each subsystem every 320 seconds. This data is then numerically combined to determine the hourly, daily, and monthly performance of the system. This appendix describes the general computational methods and the specific energy balance equations used for this evaluation.

Data samples from the system measurements are numerically integrated to provide discrete approximations of the continuous functions which characterize the system's dynamic behavior. This numerical integration is performed by summation of the product of the measured rate of the appropriate performance parameters and the sampling interval over the total time period of interest. :

There are several general forms of numerical integration equations which are applied to each site. These general forms are exemplified as follows: The total solar energy available to the collector array is given by

$$
\text { SOLAR ENERGY AVAILABLE }=(1 / 60) \Sigma[1001 \times \text { AREA }] \times \Delta \tau
$$

where 1001 is the solar radiation measurement provided by the pyranometer in Btu/ft $\mathrm{ft}^{2}-\mathrm{hr}$, AREA is the area of the collector array in square feet, $\Delta \tau$ is the sampling interval in minutes, and the factor $(1 / 60)$ is included to correct the solar radiation "rate" to the proper units of time. 
Similarly, the energy flow within a system is given typically by

$$
\text { COLLECTED SOLAR ENERGY }=\Sigma[M 100 \times \Delta H] \times \Delta \tau
$$

where M100 is the mass flow rate of the heat transfer fluid, in $1 b_{m} / \mathrm{min}$, and $\Delta H$ is the enthalpy change, in $B t u / 1 b_{m}$, of the fluid as it passes through the heat exchanging component.

For a liquid system $\Delta H$ is generally given by

$$
\Delta H=\tau_{p} \Delta T
$$

where $\bar{C}_{p}$ is the average specific heat, in $B t u /\left(1 b_{m}-{ }^{\circ} F\right)$, of the heat transfer fluid and $\Delta T$, in ${ }^{\circ} \mathrm{F}$, is the temperature differential across the heat exchanging component.

For an air system $\Delta H$ is generally given by

$$
\Delta H=H_{a}\left(T_{\text {out }}\right)-H_{a}\left(T_{\text {in }}\right)
$$

where $H_{a}(T)$ is the enthalpy, in $B t u / 1 b_{m}$, of the transport air evaluated at the inlet and outlet temperatures of the heat exchanging component.

$H_{a}(T)$ can have various forms, depending on whether or not the humidity ratio of the transport air remains constant as it passes through the heat exchanging component. 
For electrical power, a general example is

ECSS OPERATING ENERGY $=(3413 / 60) \Sigma[$ [EP100] $\times \Delta \tau$

where EP100 is the measured power required by electrical equipment in kilowatts and the two factors $(1 / 60)$ and 3413 correct the data to Btu/min.

These equations are comparable to those specified in "Thermal Data Requirements and Performance Evaluation Procedures for the National Solar Heating and Cooling Demonstration Program." This document, given in the list of references, was prepared by an inter-agency committee of the government, and presents guidelines for thermal performance evaluation.

Performance factors are computed for each hour of the day. Each numerical integration process, therefore, is performed over a period of one hour. Since long-term performance data is desired, it is necessary to build these hourly performance factors to daily values. This is accomplished, for energy parameters, by summing the 24 hourly values. For temperatures, the hourly values are averaged. Certain special factors, such as efficiencies, require appropriate handling to properly weight each hourly sample for the daily value computation. Similar procedures are required to convert daily values to monthiy values.

\section{IT. PERFORMANCE EQUATIONS}

The performance equations for Solaron Duffield used for the data evaluation of this report are contained in the following pages and have been included for technical reference and information. 
NOTE: MEASUREMENT NUMBERS REFERENCE SYSTEM SCHEMATIC FIGURE 2-1

AVERAGE BUILDING TEMPERATURE $\left({ }^{\circ} \mathrm{F}\right)$

$$
T B=(1 / 60) \times \sum T 601 \times \Delta T
$$

AVERAGE AMBIENT TEMPERATURE $\left({ }^{\circ} \mathrm{F}\right)$

$$
T A=(1 / 60) \times \Sigma T 001 \times \Delta \tau
$$

DAYTIME AVERAGE AMBIENT TEMPERATURE $\left({ }^{\circ} \mathrm{F}\right)$

$$
\begin{aligned}
\text { TDA }= & (1 / 360) \times \Sigma \text { TOO } 1 \times \Delta \tau \\
& \text { FOR } \pm 3 \text { HOURS FROM SOLAR NOON }
\end{aligned}
$$

INCIDENT SOLAR ENERGY PER SQUARE FOOT (BTU/FT ${ }^{2}$ )

$$
\mathrm{SE}=(1 / 60) \times \Sigma 1001 \times \Delta \tau
$$

OPERATIONAL INCIDENT SOLAR ENERGY (BTU)

$$
\text { SEOP }=(1 / 60) \times \Sigma[1001 \times \text { CLAREA }] \times \Delta \tau
$$

WHEN THE COLLECTOR LOOP IS ACTIVE

HUMIDITY RATIO FUNCTION (BTU/LBM- ${ }^{\circ} \mathrm{F}$ )

$$
H R F=0.24+0.444 \times H R
$$

WHERE 0.24 IS THE SPECIFIC HEAT AND HR IS THE HUMIDITY RATIO OF THE TRANSPORT AIR. THIS FUNCTION IS USED WHENEVER THE HUMIDITY RATIO WILL REMAIN CONSTANT AS THE TRANSPORT AIR FLOWS THROUGH A HEAT EXCHANGING DEVICE.

SOLAR ENERGY COLLECTED BY THE ARRAY (BTU)

$$
\begin{aligned}
\text { SECA } & =\Sigma[(M 101 \times(T 150-T 100)+(M 100-M 101) \times(T 150-T 001)) \times \text { HRF }] \times \Delta T \\
& \text { NOTE THAT THIS EQUATION ACCOUNTS FOR LEAKAGE FLOW FROM THE OUTSIDE } \\
& \text { ENVIRONMENT INTO THE COLLECTOR ARRAY. }
\end{aligned}
$$


AVERAGE TEMPERATURE OF STORAGE $\left({ }^{\circ} \mathrm{F}\right)$

$$
T S T=(1 / 60) \times \Sigma[(T 200+T 201+T 202) / 3] \times \Delta \tau
$$

SOLAR ENERGY TO STORAGE (BTU)

$$
\text { STEI }=\Sigma[0.5 \times(\text { M200 + M202) } \times \text { HRF } \times(T 102-T 152)] \times \Delta \tau
$$

SOLAR ENERGY FROM STORAGE (BTU)

$$
\text { STEO }=\Sigma[0.5 \times(\text { M200 }+ \text { M202) } \times \text { HRF } \times(T 102-T 152)] \times \Delta \tau \text {. }
$$

SOLAR ENERGY DELIVERED TO LOAD FROM STORAGE (BTU)

HSES $=$ M600 $\times$ HRF $\times(T 450-T 601)$ WHEN HEATING FROM STORAGE ENTHALPY FUNCTION FOR WATER (BTU/LBM)

$\operatorname{HWD}\left(T_{2}, T_{1}\right)=\int_{T_{1}}^{T_{2}} C_{p}(T) d T$

THIS FUNCTION COMPUTES THE ENTHALPY CHANGE OF WATER AS IT PASSES THROUGH A HEAT EXCHANGING DEVICE.

SOLAR ENERGY TO HOT WATER SUBSYSTEM (BTU)

$H W S E=\Sigma[M 301 \times \operatorname{HWD}(T 351, T 301)] \times \Delta \tau$

SOLAR ENERGY DELIVERED TO LOAD FROM COLLECCTOR ARRAY (BTU)

CSEOH1 $=$ M600 $\times$ HRF $\times(T 450-T 601)$

ECSS OPERATING ENERGY (BTU)

CSOPE $=56.8833 \times \Sigma E P 100 \times \Delta \tau$

HOT WATER LOAD (BTU)

$H W L=\Sigma[M 302 \times H W D(T 352, T .302)] \times \Delta \tau$

HOT WATER CONSUMED (GALLONS)

$H W C S M=\Sigma W D 302 \times \Delta \tau$

SOLAR ENERGY TO HOT WATER LOAD (BTU)

HWSE1 $=\Sigma[M 302 \times$ HWD $(T 303, T 302)] \times \Delta \tau$ 
HOT WATER SUBSYSTEM OPERATING ENERGY (BTU)

$H W O P E=56.8833 \times \Sigma E P 301 \times \Delta \tau$

HOT WATER SUBSYSTEM AUXILIARY ELECTRICAL FUEL ENERGY (BTU)

HWAE $=56.8833 \times \Sigma E P 302 \times \Delta \tau$

HEAT PUMP SYSTEM POWER (BTU)

$H P P W R=56.8833 \times \Sigma[E P 402+E P 404] \times \Delta \tau$

WHEN HEAT PUMP IS IN A HEATING MODE

ENERGY DELIVERED BY HEAT PUMP SYSTEM (BTU)

HTHPDIR $=\Sigma[M 201 \times H W D(T 401, T 451)] \times \Delta \tau$

WHEN HEATING DIRECTLY FROM THE HEAT PUMP

HTHPSTO $=\Sigma[$ M201 $\times$ HWD $(T 401, T 451)] \times \Delta \tau$

WHEN HEATING FROM OFF PEAK STORAGE TANK

AUXILIARY THERMAL ENERGY FROM HEAT PUMP (BTU)

HAT2 $=\Sigma[M 201 \times H W D(T 207, T 257)] \times \Delta \tau$

WHEN HEATING DIRECTLY FROM THE HEAT PUMP

HAT3 $=\Sigma[$ M201 $\times$ HWD $(T 207$, T257) $\times \Delta \tau$

WHEN CHARGING OFF PEAK STORAGE WITH HEAT PUMP

AUXILIARY ELECTRICAL FUEL ENERGY TO HEAT PUMP COMPRESSOR (BTU)

HAE $]=56.8833 \times \Sigma[E P 402-E P 403] \times \Delta \tau$

WHEN HEATING DIRECTLY FROM THE HEAT PUMP.

HAE2 $=56.8833 \times \Sigma[E P 402-E P 403] \times \Delta \tau$

WHEN CHARGING OFF PEAK STORAGE WITH HEAT PUMP

AUXILIARY ELECTRICAL FUEL ENERGY TO HEAT STRIPS (BTU)

HAE3 $=56.8833 \times \Sigma E P 401 \times \Delta \tau$ 
INCIDENT SOLAR ENERGY ON COLLECTOR ARRAY (BTU)

$$
S E A=\text { CLAREA } \times S E
$$

COLLECTED SOLAR ENERGY (BTU/FT ${ }^{2}$ )

SEC = SECA/CLAREA

COLLECTOR ARRAY EFFICIENCY

CAREF $=$ SECA/SEA

CHANGE IN STORED ENERGY (BTU)

$$
\text { STECH }=\text { STECHI }- \text { STECHI }_{p}
$$

WHERE THE SUBSCRIPT $p$ REFERS TO A PRIOR REFERENCE VALUE

STORAGE EFFICIENCY

$$
\text { STEFF }=(\text { STECH }+ \text { STEO }) / \text { STEI }
$$

ENERGY DELIVERED FROM ECSS TO LOAD SUBSYSTEMS (BTU)

$$
\text { CSEO }=\text { STEO + CSEOHT + HWSE }
$$

ECSS SOLAR CONVERSION EFFICIENCY

$$
\text { CSCEF }=\text { CSEO/SEA }
$$

SUPPLY WATER TEMPERATURE $\left({ }^{\circ} \mathrm{F}\right)$

$$
T S W=T 302
$$

HOT WATER TEMPERATURE $\left({ }^{\circ} \mathrm{F}\right)$

$T H W=T 352$

BOTH TSW AND THW ARE COMPUTED ONLY WHEN FLOW EXISTS IN THE SUBSYSTEM, OTHERWISE THEY ARE SET EQUAL TO THE VALUES OBTAINED DURING THE PREVIOUS FLOW PERIOD.

AUXILIARY THERMAL ENERGY TO HOT WATER SUBSYSTEM (BTU)

$$
\text { HWAT }=\text { HWAE }
$$

HOT WATER ELECTRICAL ENERGY SAVINGS (BTU)

$$
\text { HWSVE = HWSEI - HWOPE }
$$

HOT WATER SOLAR FRÁCTION (PERCENT)

HWSFR $=100 \times \cdot$ HWTKSE $/$ (HWTKSE + HWTKAUX)

WHERE HWTKSE AND HWTKAUX REPRESENT THE CURRENT SOLAR AND AUXILIARY ENERGY CONTENT OF THE HOT WATER TANK 
SOLAR ENERGY TO SPACE HEATING SUBSYSTEM (BTU)

HSE $=$ HSES + CSEOT

SPACE HEATING SUBSYSTEM OPERATING ENERGY (BTU)

$H O P E=.56 .8833 \times \sum[E P 400+E P 403+E P 404] \times \Delta \tau$

WHENEVER SYSTEM OPERATING IN A HEATING MODE

AUXILIARY ELECTRICAL ENERGY TO SPACE HEATING SUBSYSTEM (BTU)

$H A E=H A E 1+H A E 2+H A E 3$

TOTAL ENERGY DELIVERED BY HEAT PUMP SYSTEM (BTU)

HLHP $=$ HTHPSTO + HTHPDIR

SPACE HEATING LOAD (BTU)

$H L=H A E 3+H S E+H L H P$

AUXILIARY THERMAL ENERGY TO SPACE HEATING SUBSYSTEM (BTU)

$H A T=H A E 3+H A T 2+H A T 3$

SPACE HEATING SUBSYSTEM SOLAR FRACTION (PERCENT)

$H S F R=100 \times \mathrm{HSE} / \mathrm{HL}$

SPECIAL HEAT PUMP TERMS

NORMALIZED CAPACITY

$$
C A P N=0.325+T A \times(0.0162-0.00005 \times T A)
$$

HEAT PUMP FRACTION

$$
\begin{array}{ll}
\text { HPF }=1 & T A>40 \\
H P F=1.11 \times C A P N \times(T B-40) /(T B-T A) & 2 \leq T A \leq 40 \\
H P F=0 & T A<2
\end{array}
$$

HEAT PUMP OVERALL SYSTEM COP

$H C O P=H L H P / H P P W R$

WHERE HCOP IS BASED ON A TOTAL OF SIX

MONTHS OF SYSTEM OPERATION 
SPACE HEATING SUBSYSTEM ELECTRICAL ENERGY SAVINGS (BTU)

$$
\begin{array}{ll}
\text { HSVE }=\text { HSE } \times(\text { HPF } / H C O P+1-H C O P) & \text { IF TA } \geq 2 \\
\text { HSVE }=0.5 \times \text { HSE } \times(1+H C O P) / H C O P & \text { IF TA }<2
\end{array}
$$

SYSTEM LOAD (BTU)

$S Y S L=H L+H W L$

SOLAR FRACTION OF SYSTEM LOAD (PERCENT)

$S F R=(H L \times H S F R+H W L \times H W S F R) / S Y S L$

SOLAR ENERGY TO LOAD SUBSYSTEMS (BTU)

$$
\text { SEL = HWSE + HSE }
$$

SYSTEM OPERATING ENERGY (BTU)

$$
\text { SYSOPE = HWOPE + HOPE + CSOPE }
$$

AUXILIARY THERMAL ENERGY TO LOADS (BTU)

$$
\text { AXT = HWAT + HAT }
$$

AUXILIARY ELECTRICAL ENERGY TO LOADS (BTU)

$$
A X E=H W A E+H A E
$$

TOTAL ELECTRICAL ENERGY SAVINGS (BTU)

$$
\text { TSVE = HWSVE + HSVE - CSOPE }
$$

TOTAL ENERGY CONSUMED (BTU)

$$
\text { TECSM = SYSOPE + AXE + SECA }
$$

SYSTEM PERFORMANCE FACTOR

$$
\text { SYSPF }=S Y F L /(A X E+\text { SYSOPE }) \times 3.33
$$




\section{APPENDIX C}

LONG-TERM AVERAGE WEATHER CONDITIONS

$C-1$ 


\section{LONG-TERM AVERAGE WEATHER CONDITIONS}

The environmental estimates given in this appendix provide a point of reference for evaluation of weather conditions as reported in the Monthly Performance Reports and Solar Energy System Performance Evaluations issued by the Solar Heating, Cooling and Hot Water Development Program. As such, the information presented can be useful in prediction of long-term system performance.

Environmental estimates for this site include the following monthly averages: extraterrestrial insolation, insolation on a horizontal plane at the site, insolation in the tilt plane of the collection surface, ambient temperature, heating degree-days, and cooling degree-days. Estimation procedures and data sources are detailed in the following paragraphs.

The preferred source of long-term temperature and insolation data is "Input Data for Solar Systems" (IDSS) [1] since this has been recognized as the solar standard. The IDSS data are used whenever possible in these environmental estimates for both insolation and temperature related sources; however, a secondary source used for insolation data is the Climatic Atlas of the United States [2], and for temperature related data, the secondary source is "Local Climatological Data" [3].

Since the available long-term insolation data are only given for a horizontal surface, solar collection subsystem orientation information is used in an algorithm [4] to calculate the insolation expected in the tilt plane of the collector. This calculation is made using a ground reflectance of 0.2 . 
SITE: SOLARON DUFF.

ANALYST: L. MARTIN

COLLECTCR TILT: 40.00 (DFGREFS)

LATITUDE: $\quad 36.50$ (DEGPEFS)
LOCATION: DUFFIELD VA

FDR IVF NO : $\quad 77$.

COLLECTOR AZIMUTH: 0.0 (DERREFS)

RUN CATF: $08 / 30 / 79$

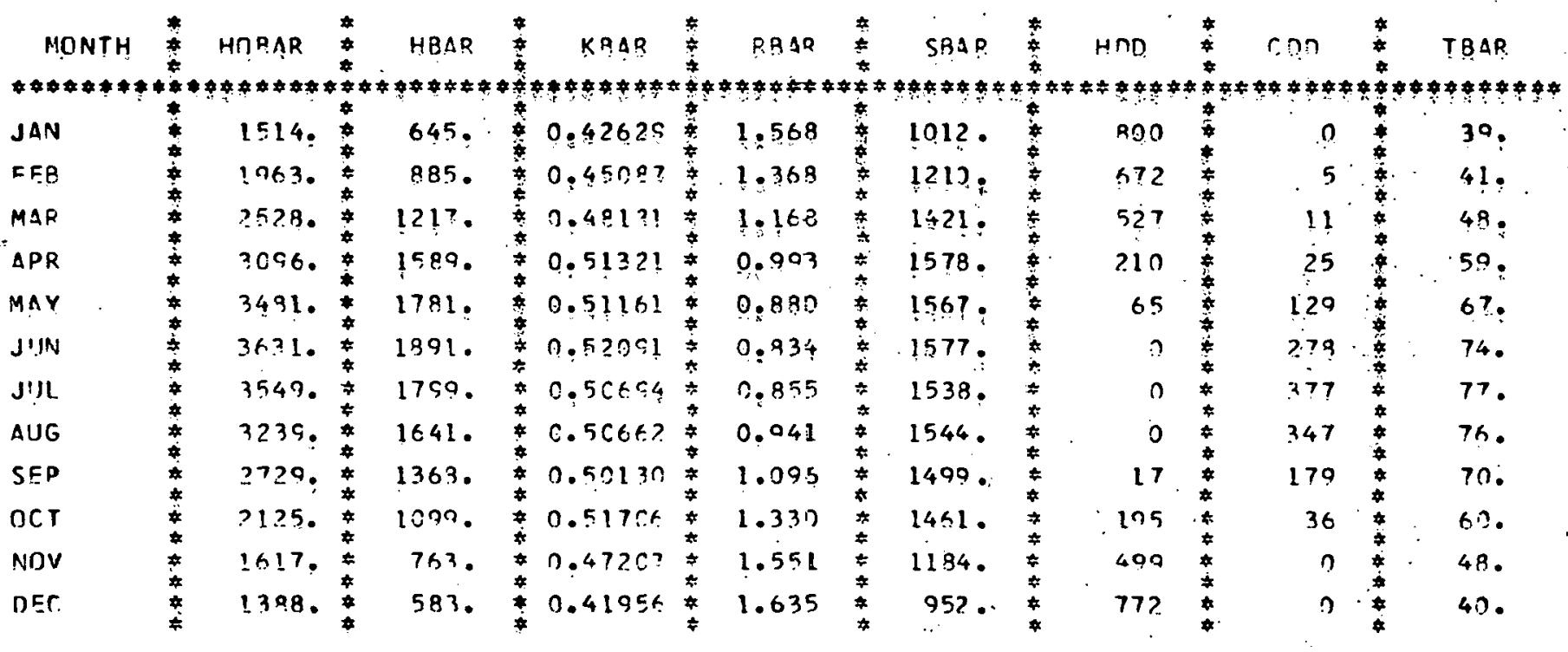

LFGEND :

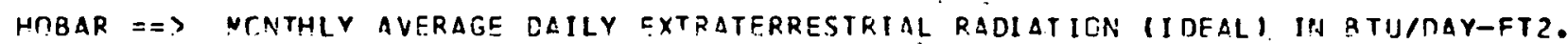

HBAR $=$ ? NCNTHLY AVEPAGE DAILY RATIATIION (ACTIIALI) IV BTUJDAY-FTZ.

KAAR ==? RATIO OF HBAP. TC HCBAR.

PBAR $\Rightarrow$ RATID OF NONTHLY AVERATE CAILYRAOIATICN ON TILTFD SURFACF TO THAT ON AA

SBAR $\Rightarrow$ MONTHLY AVERAGE DAILY RATIATION ON A TILTFE SURFACE (1.F., RBAR * HBAR) IN BTUIDAY-FT2.

HDD $=\Rightarrow$ NUMAER OF HFATING DEGRFE DAYS PER MONTH.

COD $==>$ NLMAER OF CCOLING DEGRFE TAYS PER MONTH.

THAR $\Rightarrow$ AVERAGF. AMBIFNT TFMPERATURE IN DEGREFS FAHRENHFIT. 


\section{REFERENCES}

[1] Cinquemani, V., et al. "Input Data for Solar Systems." Prepared for the U.S. Department of Energy by the National Climatic Center, Asheville, NC, 1978.

[2] United States Department of Comerce; Climatic Atlas of the United States, Environmental Data Service, Reprinted by the National Oceanic and Atmospheric Admintstration, Washington, DC, 1977.

[3] United States Department of Commerce, "Local Climatological Data," Environmental Data Service, National Oceanic and Atmospheric Administration, Ashevtlie, NC, 1977.

[4] Klein, S. A., "Calculation of Monthly Average Insolation on Tilted Surfaces," Joint Conference 1976 of the International Solar Energy Society and the Solar Energy Society of Canada, Inc., Winnipeg, August 15-20, 1976. 